\title{
REORGANIZING THE INSOLVENT OIL AND GAS CORPORATION: THE COURTS AND FAIRNESS
}

FRANK R. FORAN, Q.C. TERRENCE M. WARNER*

\begin{abstract}
The authors discuss how, once all the concerned parties have concluded an agreement, a financially troubled organization can be reorganized. Aside from proceeding under Part III of the Bankruptcy Act or under the Companies' Creditors Arrangement Act, the authors note that such a reorganization can be, and has been, effected under the Business Corporations Act. The authors discuss the details of the CBCA reorganization, and explain how courts have given great latitude to insolvent corporations, to allow them to reorganize.
\end{abstract}

\section{INTRODUCTION}

The corporate and financial reorganization of a large, intricate, publicly-traded oil and gas corporation due to its insolvency is a mammoth task. The reorganization may involve not only the corporation itself but also a number of other corporations including subsidiaries. It may be accomplished by the insolvent corporation dealing with its creditors and shareholders on its own or may involve an acquisition by another corporation accompanied by amalgamations, exchanges of securities, and a complete restructuring of debt and ownership. In this paper, the reorganization of an insolvent corporation, whether by compromise with its own creditors and shareholders alone or by way of acquisitions, amalgamations or exchanges of securities with other corporations, is referred to as a "reorganization". The plan for a reorganization is referred to interchangeably as a "reorganization plan" or "plan of arrangement" or simply a "plan".

The task of reorganization will require legal expertise in numerous areas including corporate law, securities law, oil and gas law, tax law, human resources (employment) law, insolvency law, competition law, international law and litigation. Obviously, any large scale reorganization involves extensive negotiations between the corporation and its major creditors. For any plan to have a chance of success the debtor must have assurances from major creditors, usually banks, that they will support the plan, refrain from taking steps to realize on their security, and continue funding during the period required to place the plan before the creditors, shareholders and the court. It is crucial during the time in which a plan is being finalized and considered by the various tiers of interested persons that the corporation continue as a going concern.

A successful reorganization plan requires an incredible amount of patience, flexibility and determination on the part of corporate management and the major creditors. It may involve the directors obtaining costly opinions as to the fairness of the proposed organization. It involves the preparation of detailed information circulars for creditors and shareholders and a critical determination at an early stage as to what information is to be included in the circular. Generally, the major secured creditors have received extensive information about the corporation on an ongoing basis which lesser creditors and shareholders may not have received. The level and adequacy of disclosure to all creditors and shareholders may become a central issue at subsequent court hearings. 
This paper assumes that the insolvent debtor, its major creditors and perhaps other corporations have concluded an agreement to reorganize the financially troubled corporation. Such an agreement may have taken months, perhaps years, to negotiate. Obviously, as negotiations proceeded the legal structure of the plan became fleshed out. The reorganization may be in part tax driven which can make the plan of arrangement more complex than would otherwise be necessary.

In determining the legal framework in which to proceed, basic questions must be answered. Must federal insolvency statutes be used? Can the reorganization and arrangement provisions of the Canada Business Corporation Act, R.S.C. 1985, c. C-44 (" $C B C A$ ') or the Business Corporations Act (Alberta), S.A. 1981, c. B-15 (" $A B C A$ ") be considered as viable alternatives to traditional insolvency legislation? Can an exchange of securities under the $C B C A$ or the $A B C A$ wherein creditors and shareholders receive new security instruments in return for existing security instruments accomplish the reorganization? Can debt be compromised under the $C B C A$ and the $A B C A$ ? Are the considerations for classes, voting levels and court approval the same under the various statutes? Can proceedings by secured and unsecured creditors and other third parties be stayed? At the end of the whole process, will the court declare the plan to be fair to all?

This paper does not deal with liquidations under a bankruptcy or receivership, although clearly the sale of a corporation's assets in a bankruptcy or receivership effects a fundamental reorganization of that corporation.

Until recently there have been two principal ways of reorganizing an insolvent corporate debtor: Part III of the Bankruptcy Act, R.S.C. 1985, c. B-3 ("Bankruptcy Act') governing proposals and the Companies' Creditors Arrangement Act, R.S.C. 1985 , c. C-36 (' $C C A A$ "). Recently, however, the arrangement provisions of the $C B C A$ were utilized to effect the largest corporate reorganization in Canadian history, the acquisition and reorganization of Dome Petroleum Limited ("Dome") by Amoco Canada Petroleum Company Ltd. ("Amoco Canada"). A discussion of these statutes, primarily the $C C A A$ and the $C B C A$ follows. It will be apparent that a number of recent judgments dealing with these statutes stress the public policy of promoting the continuance of insolvent corporations. The courts have gone a long way to ensure that insolvent corporations have the time and the opportunity to reorganize.

\section{PROPOSALS UNDER PART III OF THE BANKRUPTCY ACT}

It is not our intention to discuss in detail proposals under Part III of the Bankruptcy Act. Many articles have been written on the use of Part III. ${ }^{\prime}$ However, the proposal sections have been used extensively over the years to effect many corporate reorganizations and therefore a summary of Part III of the Bankruptcy Act is warranted.

Pursuant to Part III an insolvent person, including by definition a corporation whether in bankruptcy or not, may make a proposal to its creditors. The proposal proceedings are commenced by filing with a licensed trustee in the case of an insolvent person and by lodging with the trustee in bankruptcy in the case of a bankrupt, a copy of the proposal which sets out the terms that are being offered

1. See, for example, Marantz R.G., "Let's Make A Deal" (1984) 9 Canadian Business Law Journal 44. 
and the particulars of any securities or sureties proposed. Certain prescribed financial information must be served with the proposal on the creditors of the corporation. A proposal by a bankrupt must be approved by the inspectors before being pursued. The trustee under the proposal must call a meeting of the creditors by forwarding by registered mail to every known creditor a notice of the date, time and place of the meeting together with other material stipulated by s. 51 of the Bankruptcy Act.

The proposal sections of the Bankruptcy Act contain one significant restriction on the effective use of Part III by an insolvent corporation: secured creditors are not bound by the proposal. Section 54 of the Bankruptcy Act states: "subject to the rights of secured creditors, the creditors may by special resolution resolve to accept the proposal as made or altered or modified at the meeting . . ." (emphasis added). Accordingly, a major drawback in corporate reorganizations under Part III of the Bankruptcy Act is that secured creditors must be accommodated outside the proposal. Further, preferred claims such as any Crown debts must be paid in priority to other claims (s. 60). The Bankruptcy Act provides only limited powers for a trustee to stay or postpone the rights of secured creditors. Section 69(2) of the Bankruptcy Act provides that in a bankruptcy or a proposal a secured creditor may realize or otherwise deal with his security unless the court otherwise orders and in so ordering the court shall not postpone the right of the secured creditor to realize or otherwise deal with his security for a period of more than six months. The courts have been extremely reluctant to make an order preventing a secured creditor from dealing with its security. Section 69(2) will primarily be utilized by a trustee in bankruptcy who wishes time to ascertain whether there is any surplus value to the assets covered by the security which could benefit the estate. The Bankruptcy Act (ss 79-81, and 127-134) provides the mechanism whereby a trustee may gather full details of any security claimed by a secured creditor and the value thereof.

A proposal under the Bankruptcy Act can be extremely flexible and, provided that certain minimum requirements are met, can be as innovative as the draftsman believes necessary to make the proposal acceptable. However, s. 57 of the Bankruptcy Act provides that if the proposal fails, the debtor shall be deemed to have made an assignment in bankruptcy on the day the proposal was filed. If, however, the proposal is accepted by the creditors, $s$. 58 requires the trustee to apply to the court forthwith for approval and provide notice of the application to the debtor and every creditor who has proved his claim.

There have been many cases relating to the court approval process. The court is generally reluctant to substitute its discretion for that of the majority of the creditors although there are circumstances where the court will reject a proposal despite the wishes of the majority. The court's main concern is whether or not the proposal is in the best interest of the creditors. A proposal accepted by the creditors and approved by the court is binding on all creditors with claims provable under the Bankruptcy Act (i.e. preferred and unsecured creditors) and affected by the terms of the proposal but does not release the debtor from certain stipulated debts and liabilities (see s. 178). Section 66(1) provides that all the provisions of the Bankruptcy Act, insofar as they are applicable, apply mutatis mutandis to proposals. Section 66(2) further states that nothing therein shall be deemed to affect the operation of the $C C A A$ but the court may order that a proposal made by a corporation may be taken up and continued under the $C C A A$. 
Pursuant to the definition of "special resolution" contained in the Bankruptcy Act a proposal must be accepted by a majority in number and three-fourths in value of the creditors present and voting either in person or by proxy (voting letters) at the meeting of the creditors called to consider the proposal. Section 54(2) permits the creditors to vote by classes but the vote of one class is not binding on the others. "Class" is not defined. A discussion of what constitutes a "class" is set out later in this paper.

There have been numerous cases which have considered whether all unsecured creditors must be treated equally under a proposal. These cases generally deal with undisclosed advantages being provided to one creditor to induce a favourable vote. The cases state unequivocally that creditors should receive equal treatment and that the court will not tolerate the receipt by one creditor of undisclosed benefits or advantages that are not offered to other creditors. As noted by L.W. Houlden ${ }^{2}$ (now Mr. Justice Houlden) in a case comment on Sadler Manufacturing Company Ltd. v. Golt: ${ }^{3}$

It has been repeatedly held that in matters of compromise of debts there must be equality between creditors.

A secret bargain which violates that equality is null and void and will not be enforced . . . Thus, if

a guarantee is given to obtain a consent to a compromise which guarantee is not given to all creditors,

it will not be enforced by the courts ...

This same concern applies to class votes under the $C C A A$ or any other statute that permits classes of creditors and shareholders to vote on a reorganization plan.

While the proposal sections of the Bankruptcy Act do not bind secured creditors, and hence will not normally involve the participation of such creditors, it has been held that in certain circumstances a secured creditor does have the right to participate in proceedings brought for court approval pursuant to the proposal. In Re: Cadillac Explorations Limited (No. 2); Cadillac Explorations Limited v. Procan Exploration Company, ${ }^{4}$ the British Columbia Supreme Court ruled that the key issue is whether or not a secured creditor is a creditor that is affected by the proposal. The court determined that a secured creditor is unquestionably a "creditor" under the definition contained in s. 2 of the Bankruptcy Act and if he is affected by the proposal the trustee is required to send notice of the meeting of creditors to him and give him notice of the court application for approval. While a secured creditor is specifically disentitled from voting on the proposal by s. 112 of the Bankruptcy Act (except in respect of the portion of its claim that is unsecured) the secured creditor is fully entitled to participate in subsequent court proceedings if the proposal affects him.

\section{COMPANIES' CREDITORS ARRANGEMENT ACT}

\section{A. PURPOSE OF THE LEGISLATION}

The CCAA was first introduced in the 1932 session of Parliament and has undergone little change since inception. The Honourable C.H. Cahan, who introduced the legislation in the House of Commons, indicated that it was designed to

2. (1956), 35 C.B.R. 71 at 71.

3. (1956), 35 C.B.R. 67 (Que. C.A.).

4. (1985), 51 C.B.R. (N.S.) 178; affg. (1985), 52 C.B.R. (N.S.) 37. 
"permit a corporation through reorganization, to continue its business and thereby to prevent its organization being disrupted and its goodwill lost".

Some courts in considering the $C C A A$ have elevated the goal of corporate preservation through reorganization to a matter of public policy. In view of this public policy consideration, the courts have indicated on several occasions that the provisions of the $C C A A$ will be broadly construed to facilitate effective reorganizations. $^{6}$

An early constitutional reference determined that the $C C A A$ was valid bankruptcy and insolvency legislation. ${ }^{7}$ The courts, however, have consistently held, with one or two notable exceptions, that the CCAA is not to be utilized to dismantle a corporate entity as can be done under bankruptcy or winding-up legislation. For example, in the Oakwood Petroleums decisions Mr. Justice Forsyth stated clearly that the $C C A A$ was designed to "allow debtor companies to continue to carry on their business . . . rather than to liquidate companies".

In contrast is the recent Alberta decision of Re Associated Investors of Canada Ltd.; Re First Investors Corporation Ltd. ${ }^{9}$ Mr. Justice Berger was faced with a plan of arrangement conceived by the receiver-manager of the two debtor corporations which contemplated the liquidation of the corporations. Mr. Justice Berger stated at page 267:

In my opinion, the Companies' Creditors Arrangement Act is not restricted in its application to companies which are to be kept in business ... The Act may be invoked as a means of liquidating a company and winding up its affairs but only if certain conditions precedent are met:

1. It must be demonstrated that benefits would likely flow to creditors that would not otherwise be available if liquidation were effected pursuant to the Bankruptcy Act or the Winding-Up Act.

2. The court must concurrently provide directions pursuant to compatible legislation that ensures judicial control over the liquidation process and an effective means whereby the affairs of the company may be investigated and the results of that investigation made available to the court.

3. A plan of arrangement should not receive judicial sanction until the court has in its possession all of the evidence necessary to allow the court to properly exercise its discretion according to standards of faimess and reasonableness, absent any findings of illegality.

It is submitted that notwithstanding the decision in Re Associated Investors, the primary purpose of the $C C A A$ is not to facilitate the liquidation of corporations but to enable insolvent corporations to reorganize their business affairs under judicial supervision with a view to continuance. The primary advantage of the $C C A A$ over Part III of the Bankruptcy Act is that anyone with a claim against the insolvent corporation, including secured creditors, may be subject to the plan.

5. S.E. Edwards, "Reorganizations Under the Companies' Creditors Arrangement Act" (1947) 25 Can. Bar Rev. 587 at 592.

6. See for example: Norcen Energy Resources Lid. v. Oakwood Petroleums Lid: (1989), 92 A.R. 81 ("Oakwood Petroleums (No. 1)"); Norcen Energy Resources Lid. v. Oakwood Petroleums Ldd. (1989), 64 Alta. L.R. (2d) 139 (“Oakwood Petroleums (No. 2)”).

7. Re: Companies' Creditors Arrangement Act (1934-35), 16 C.B.R. 1 (S.C.C.).

8. Oakwood Petroleums (No. I) at 84; Oakwood Petroleums (No. 2) at 146 - supra, note 6; see also, Re D.W. McIntosh Limited (1938-39), 20 C.B.R. 234; Re Avery Construction Company Limited (1942-43), 24 C.B.R. 17; Re Arthur Flint Co. Ld., [1944] 3 D.L.R. (2d) 13; Quebec Steel Products (Indust.) Ld. v. James United Steel Lsd. (1969), 5 D.L.R. (3d) 374.

9. (1988), 56 Alta. L.R. (2d) 259. 


\section{B. COMMENCEMENT OF THE CCAA APPLICATION}

\section{The Applicant}

Part 1 of the $C C A A$ in s. 4 and 5 refers to a number of parties who may bring an application under the Act. These are:

(1) the debtor corporation;

(2) any creditor of the corporation;

(3) the trustee in bankruptcy; or

(4) the liquidator of the corporation appointed pursuant to the Winding-Up Act, R.S.C. 1985 , c. W-11.

It would be a rare occasion for a party other than the debtor corporation to bring an application for several reasons. A corporation intent on survival will in all likelihood have sought, prior to an application under the $C C A A$, alternative avenues to reorganize its debt load. Typically, $C C A A$ applications are "1lth hour" applications by corporations in dire financial distress. Creditors generally favour realizing on any security they have rather than looking for ways to preserve the corporation as a going concern unless they can see immediate benefits. As far as a trustee in bankruptcy or a liquidator is concerned. By the time they are appointed there may be little of the corporation worth salvaging. The corporation's secured creditors will have either taken steps to realize upon their security or will be on the verge of doing so and the corporation may be beyond rescue.

It should be noted that an application can be brought by the corporation even following its bankruptcy or the appointment of a liquidator. Section 66(2) of the Bankruptcy Act states:

Nothing in this Act shall be deemed to affect the operation of the Companies' Creditors Arrangement Act and the Court may order that a proposal made by a corporation pursuant to section 50 be taken up and continued under the Companies' Creditors Arrangement Act.

There is also authority for the proposition that a debtor corporation may bring an application under the $C C A A$ following the appointment of a receiver. This is in effect what occurred in the recent Nova Scotia case Re United Maritime Fishermen Co-op; Re Bluenose Fisheries Limited.$^{10}$ Richard C.J.Q.B. states at page 57 of his judgment:

I find that the Act (i.e. the CCAA) is so written as to apply at almost any stage of insolvency and bankruptcy ...

It is arguable that this would be the case whether the receiver is appointed under an instrument or by court order under the Judicature Act or $A B C A$, for the reason that the $C C A A$ is federal insolvency legislation and should therefore take precedence over provincial legislation pursuant to which a receiver is appointed."

\section{Conditions Precedent to Application}

Sections 2 and 3 of the $C C A A$ establish certain criteria that must be met before the CCAA will have application in any given circumstance. First of all, the corporation must be a "company" as defined in $\mathrm{s}$. 2 . The definition is very broadly

10. (1988), 67 C.B.R. (N.S.) 44.

11. See Montreal Trust Company v. Abitibi Power \& Paper Co. Ldd. [1938] O.R. 589; Re Companies' Creditors Arrangement Act, supra, note 7. 
drafted and includes any company or corporation incorporated in Canada either federally or provincially, any incorporated company wherever incorporated having assets in Canada, or any corporation doing business in Canada. It excludes banks, railway or telegraph companies, insurance and trust companies.

The second criterion is that the corporation must be a "debtor company" as defined in s. 2. Again, this definition is very broadly drafted and includes any corporation that is bankrupt or insolvent, or has committed an act of bankruptcy as defined in the Bankruptcy Act, or is deemed insolvent within the meaning of the Winding-Up Act. As previously indicated, the $C C A A$ applies whether or not proceedings in respect of the corporation have been taken under the Winding-Up Act or the Bankruptcy Act.

The third criterion is that, under s. 3, the debtor company must have outstanding at the time of application an issue of secured or unsecured bonds, debentures, debenture stock or other evidence of indebtedness, issued under a trust deed or other instrument running in favour of a trustee. Without the prior existence of such a trust deed the court has no jurisdiction whatsoever to grant an application under the $C C A A .^{12}$ This provision did not appear in the original legislation passed in 1933 but was an amendment introduced in 1952 for the purpose of limiting the applicability of the CCAA. The then Minister of Justice, the Honourable Mr. Garson who introduced the amendment, indicated that the Government's intention was to restrict the availability of the $C C A A$ to corporations that had complex financial structures and a large number of investor creditors. ${ }^{13}$ Practically speaking, this requirement has become little more than a technical barrier as it has become commonplace for corporations considering an application under the $C C A A$ to issue a trust deed and bonds or debentures thereunder solely for the purpose of complying with s. 3 of the Act. The bona fides of the creation of such debt instruments has been challenged on at least one occasion. ${ }^{14}$ However, the courts are reluctant to set them aside in view of the overriding public policy considerations favouring reorganization.

In the Re Bluenose Fisheries Limited ${ }^{15}$ case, the directors of the corporation executed and registered a trust deed one day prior to an application under the $C C A A$. There was no question in the case that the trust deed was created solely to comply with the provisions of the $C C A A$. A secured creditor of the corporation took issue with the trust deed arguing that it had no business purpose as its only purpose was to enable the Corporation to comply with the $C C A A$. The court ruled against the secured creditor's argument stating at p. 56:

I agree with counsel for U.M.F./Bluenose that the Act "does not impose any time restraints on the creation of the conditions as set out in $\mathrm{s.} 3$ of the Act, nor does it contain any prohibition against the creation of conditions set out in s. 3 for the purpose of obtaining jurisdiction".

Questions have arisen as to the validity of a trust deed issued by an insolvent corporation following its placement into receivership for the sole purpose of complying with the $C C A A$. The court in the Re Bluenose Fisheries Limited ${ }^{16}$ case refused to set aside such a trust deed rejecting arguments that its creation was a fraud upon the creditors of the corporation in that it had no business purpose. The trust

12. Re Canadian Bed \& Breakfast Registry Ldd. (1987), 65 C.B.R. (N.S.) 115.

13. Re Bluenose Fisheries Limited, supra, note 10.

14. Ibid.

15. Ibid.

16. Ibid. 
deed was attacked as well on the basis that the directors had no authority to issue the trust deed following the receiver's appointment because their powers were suspended during the currency of the receiver's appointment. The court stated, however, that the $C C A A$ does not prevent such a course of action from being taken.

Richard C.J.Q.B. concluded:

The language of the Act leaves no doubt in my mind that, regardless whether or not the floating charge had crystallized and regardless whether the receiver manager had been appointed prior to or after the creation of the trust deeds, the Act was intended to apply and I find that it does apply.

There is judicial conflict on this point. Mr. Justice Forsyth in the case of Re Hat Development Ltd. ${ }^{17}$ declined to follow the Bluenose decision. The Hat Development case involved a court appointed receiver-manager. As in the Bluenose case, the directors of the corporation issued a trust deed following the appointment of the receiver-manager and bonds were issued pursuant to the trust deed. The court ruled that the directors did not have the authority to issue the trust deed. The trust deed created further indebtedness on the part of the corporation which only the receiver-manager was empowered to do. The court stated at page 268 that the receiver-manager was:

... empowered by the Court to manage the affairs of the company and it is completely inconsistent with that function to suggest that some residual power lies in the hands of the directors of the company to create further indebtedness of the company and thus interfere, however slightly with the ReceiverManager's ability to manage.

It is noteworthy, however, that the court left open the possibility of the directors in an appropriate case applying to the court to seek a variation of the powers of the receiver-manager sufficient to allow the directors to issue the indebtedness on behalf of the corporation. The approach of Justice Forsyth seems correct. The question is not so much whether the $C C A A$ can apply to a corporation in receivership but rather who can exercise the powers on behalf of the corporation to seek the protection of the $C C A A$. Upon the appointment of a receiver or receivermanager under the provisions of both the $A B C A$ and the $C B C A$ the powers of the directors of the corporation that the receiver-manager is authorized to exercise may not be exercised by the directors. ${ }^{18}$ The proper approach is to ascertain what powers may be exercised by the receiver-manager and what powers, if any, remain with the directors.

\section{Application in the Absence of a Plan}

A number of recent applications under the $C C A A$ have commenced with a preliminary motion by the applicant seeking three forms of relief from the court:

(1) a declaration that the $C C A A$ applies to the corporation;

(2) an order that the corporation file a plan of arrangement within a prescribed time, and that there be within the plan provisions for the holding of meetings; and

(3) an order staying all "actions, suits or other proceedings" against the corporation.

A question that has arisen is whether a plan must be in place prior to an application being brought under the $C C A A$. A strict reading of the $C C A A$ tends to lead to an affirmative answer. It appears that the initial application must be brought pursuant to s. 4 and s. 5. The language of these sections suggests that the applicant

17. (1989), 71 C.B.R. (N.S.) 264.

18. $A B C A$ s. $91 ; C B C A$ s. 96. 
must have in hand as of the date of the initial application an arrangement proposal and that the first order under the $C C A A$ will be the convening of meetings of creditors to consider the plan that has been proposed. There are no other apparent provisions within the $C C A A$ pursuant to which an initial application can be brought. Hence, in the absence of a proposal, the court may have no jurisdiction to make an order.

It has also been argued that the court has no jurisdiction to issue a stay under s. 11 unless and until an actual plan of arrangement has been proposed. The language of $s$. 11 suggests that this section will not be engaged until an application is brought under s. 4 or s. 5 . However, actual practice and a preliminary decision by Mr. Justice Forsyth in the reorganization of Oakwood Petroleums Ltd. ${ }^{19}$ indicate that the reverse is true.

Oakwood brought an application to extend the stay granted in the initial order which was set to expire. The opposing creditors argued that the court had no jurisdiction to extend the stay as in the absence of a plan of arrangement the $C C A A$ had no application. In ruling against this argument, Mr. Justice Forsyth stated: ${ }^{20}$

\footnotetext{
I have considered the intent and effect of this Act and in my judgement the Act must be interpreted in a practical way to accomplish what was intended which was to allow corporations finding themselves in financial difficulty an opportunity within a reasonable time and without prejudicing other creditors, if possible, or other parties affected, if possible, to put together a proposal or arrangement to work their way out of that difficulty ...

I do not interpret s. 3 as requiring before the Act comes into play, that there be a firm compromise or arrangement proposed. . . . Section 11 under which this present application for an extension of time is framed . . . in my judgement can be read separate and distinct from Part I and from s. $3 \ldots$. . Accordingly, I find that the court has jurisdiction to deal with this application.
}

The Oakwood decision is a practical one having regard to the complexities involved in the preparation of a realistic plan of arrangement. Given the fact that applications under the $C C A A$ are usually " 11 th hour" type applications by corporations in financial distress, the corporation will require the protection of the stay provision of the $C C A A$ to allow it breathing space while it puts together a plan of arrangement. ${ }^{21}$

\section{Getting To Court}

Section 10 of the $C C A A$ provides that the application under the $C C A A$ can be commenced either by way of Petition or by way of Originating Notice, in accordance with the practice of the court to which the application is made. The application is to be made in a summary way to a court having superior jurisdiction. In Alberta, the application is made to the Court of Queen's Bench. Section 9(2) provides that the powers conferred by the $C C A A$ may be exercised by a single judge in chambers. The Rules of Court applicable in the jurisdiction in which the application is brought govern all such applications.

Section 9(1) of the Act sets out several options with regard to the jurisdiction in which to bring an application. An application under the $C C A A$ may be made to the court:

19. Oakwood Petroleums (No. I) and (No. 2), supra, note 6.

20. This decision was rendered orally by Mr. Justice Forsyth on October 31, 1988 at p. 39-40 Transcript of Proceedings.

21. See also CCAA application of Lochiel Oil and Gas - Alberta Court of Queen's Bench J.D. of Calgary action No. 8601-06507 where the stay was granted before the plan was concluded. 
(1) having jurisdiction in the province in which the head office of the corporation is situated;

(2) where the chief place of business of the corporation is located; or

(3) in any province within which the corporation has assets.

The court will retain the discretion to make determinations in respect of the appropriate forum for such applications.

Under s. 16, every order made by the court in any jurisdiction shall have full force and effect in all Provinces and shall be enforced in the court of each Province in the same manner as if the order had been made in that Province.

A further discussion of the summary proceedings provided for in the $C C A A$ and $C B C A$ is found, infra, under Part VII.

\section{Notice Requirements}

There is some debate as to whether the initial application brought under the $C C A A$ should be made ex parte or upon notice to all affected parties. Under the Alberta Rules of Court, an Originating Notice normally requires ten clear days notice before an application can be brought. If the corporation is on the verge of collapse it will not wish to give much advance notice to its creditors, which may only serve to prompt them to proceed with their own actions. The practice has been followed in some cases for counsel to commence the proceedings and seek immediate ex parte orders.

Some Judges have considered such applications for ex parte orders to be of questionable propriety. For example, in the case $\operatorname{Re} 229351$ B.C. $L t d .{ }^{22}$ Hind J. of the B.C. Supreme Court commented:

Sections 4 and 5 of the Act refer to an application "in a summary way". That does not necessarily mean an application ex parte, which was the procedure followed in this case.

An exparte application should not be made without a careful assessment of whether such an application is justified in the circumstances. The rules of the Law Society should be carefully examined especially where counsel for the applicant is aware that certain creditors and shareholders have retained their own counsel.

The normal rules regarding ex parte applications will apply to $C C A A$ applications. In such situations the applicant's solicitor has a high onus to bring to the court's attention all material information including the existence of other counsel. In the 229351 B.C. cas $^{23}$ the court commented that the material filed in support of the ex parte application failed to disclose material information concerning the state of the applicant's finances. Although the court did not give any indication that it would not have granted the application had that material been available, there is a very strong suggestion that it disapproved of the ex parte procedure followed in those circumstances.

Of course, simply complying with the preconditions to the application does not guarantee that the court will grant an application under the $C C A A$. For example, in the case In Re Avery Construction Company Limited ${ }^{24}$ Urquhart J. refused an application under the $C C A A$ for the reason that the applicant was hopelessly

22. Unreported, 16 January 1989, Vancouver Registry No. A88 1623 (B.C.S.C.).

23. Ibid.

24. (1942-43), 24 C.B.R. 17. 
insolvent and could not have survived even if a plan of arrangement could have been put together.

\section{Stay of Proceedings}

From the perspective of a corporation in financial difficulty, s. 11 of the $C C A A$ is an extremely valuable tool as it creates a mechanism whereby the corporation can keep not only its creditors at bay, but also anyone else contemplating proceedings. Invariably, applications under the $C C A A$ will include a request for a stay pursuant to s. 11, which states:

Notwithstanding anything in the Bankruptcy Act or in the Winding-Up Act, whenever an application has been made under this Act in respect of any company, the court, on the application of any person interested in the matter, may, on such notice to any other person, or without notice as it may see fit,

(a) make an onder staying until such time as the court may prescribe or until further order all proceedings taken or that might be taken in respect of such company under the Bankruptcy Act and the Winding-Up Act or either of them;

(b) restrain further proceedings in any action, suit or proceeding against the company upon such terms as the court sees fit, and;

(c) make an order that no suit, action or other proceeding shall be proceeded with or commenced against the company except with the leave of the court and subject to such terms as the court imposes.

The stay may be applied for by any interested person, not merely the corporation. This is in keeping with the fact that there are a variety of parties listed in s. 4 and s. 5 who are entitled to bring a $C C A A$ application on behalf of the debtor corporation.

It is important to give careful consideration to the language of the stay order being sought. Given the fact that a stay of a potential litigant's rights to proceed against the corporation is an extraordinary provision, courts in the past have indicated that the language granting the stay will be strictly construed.

In In Re Arthur Flint Company Limited ${ }^{25}$ a petition in bankruptcy was brought by a group of creditors of the debtor corporation subsequent to an order under the $C C A A$. In that case a stay had been granted but the stay applied only to unsecured creditors and did not contemplate bankruptcy proceedings. Later a second stay order was obtained which the court ruled was even narrower than the first order. As the stay did not affect the secured creditors of the debtor corporation, the secured creditors took steps to realize upon their security. The court granted the bankruptcy petition as it determined that the secured creditors had seriously undermined the viability of the proposal and impaired the corporation's ability to survive. For this reason and because the stay did not restrain bankruptcy proceedings the court felt it had no choice but to grant the petition in bankruptcy.

In Gray v. Wentworth Canning Company Limited ${ }^{26}$ the debtor corporation applied for and received an order in the following terms:

And It Is Further Ordered that until these proceedings under The Companies ' Creditors Arrangement $A c t$ have been fully disposed of, no proceedings under the Bankruptcy Act, the Winding-Up Act or any suit or proceeding of any nature against the Company shall be taken, except with the authorization of this Court.

The matter before the court involved an application for payment out of court of monies that had been paid into court pursuant to a garnishee summons. The plain-

25. (1944), 25 C.B.R. 156.

26. (1951), 31 C.B.R. 182. 
tiff's action had been commenced prior to the application under the $C C A A$. The court ruled that the stay provision served to prohibit only the commencement of future suits or proceedings against the company. Because the plaintiff's action was commenced prior to the application under the $C C A A$, the stay had no application.

Recent practice has been to include in the provisions of the stay both general terminology keying on the language of $\mathrm{s}$. 11 as well as specific provisions tailored to the particular business of the applicant so that no doubt remains as to what is or what is not contemplated within the provisions of the stay. For example, the order that was granted by Mr. Justice Forsyth in the reorganization of Oakwood was cast in the following terms:

AND THIS COURT FURTHER ORDERS that save and except for the matters referred to in paragraph 11 herein:

(a) all proceedings taken or that might be taken by any of Oakwood's creditors under the Bankruptcy Act, R.S.C. 1970, c. B-3 and the Winding-Up Act, R.S.C. 1970, c. W-10, or either of them shall be stayed until further Order of this Court,

(b) that all further proceedings in any action, suit or proceeding against Oakwood, its assets, property, and undertaking shall be restrained until further Onder of this Court;

(c) that no proceedings shall be proceeded with or commenced against Oakwood, its assets, property and undertaking except with leave of this Court with notice to Oakwood and subject to such terms as this Court may impose, and without limitation to any of the foregoing,

(i) all persons are enjoined and restrained from realizing upon or otherwise dealing with any security held by that person on the property, assets and undertaking of Oakwood until further Order of this Court, and

(ii) all persons, having rights under the terms of any operating agreements with Oakwood are enjoined and restrained from taking proceedings to remove Oakwood as operator of such petroleum and natural gas properties and facilities, notwithstanding any provision contained in the said Agreements to the contrary, until further Order of this Court.

The jurisdiction of the court under s. 11 to make such sweeping kinds of orders virtually staying every type of proceedings has been challenged. However, two recent Alberta decisions, have ruled that the language of $s .11$ should be interpreted broadly.

Mr. Justice Wachowich in the Meridian Developments ${ }^{27}$ case stated at page 223 that "[i]t is necessary to give this section a wide interpretation in order to ensure its effectiveness." Similarly, Mr. Justice Forsyth in the Oakwood Petroleums (No. 1) 2 $^{28}$ case stated that the wording of $\mathrm{s.} 11$ is extraordinarily broad.

Two questions arise. Firstly, can a stay granted pursuant to $s .11$ restrain extrajudicial steps taken by the creditor to realize upon his security, normally a matter of contract as between the debtor corporation and the security holder? Secondly, can such a stay restrain actions by parties who are not, strictly speaking, creditors? The answer to each question is dependent on the meaning of the word "proceeding" in $\mathrm{s} .11$. This word has been considered by the courts in a number of cases. The Gray v. Wentworth Canning ${ }^{29}$ case suggests that the word "proceeding" refers to activities involving the courts or court officials. This narrow interpretation is apparent at page 185 of the decision where Kelly, J. states:

In my opinion, the word "proceeding" in the order is governed by the preceding word "suit" and, as a result, it was intended that no suit or similar proceedings should thereafter be taken against the company.

27. [1984] 5 WWR 215.

28. Supra, note 6.

29. Supra, note 26. 
Justice Wachowich in the Meridian Development ${ }^{30}$ case consulted a variety of authorities, most of which seemed to restrict the meaning of the word "proceeding" to actions that involved the use of the courts or court officials. He decided, however, that the word "proceeding" must be given a broader interpretation. Justice Wachowich states at page 223:

These arguments are persuasive. Nonetheless, I am mindful of the wide scope of action which Parliament intended for this section of the Act. To narrow the interpretation of "proceeding" could lessen the ability of a court to restrain a creditor from acting to prejudice an eventual arrangement in the interim when other creditors are being consulted. As I indicated earlier, it is necessary to give this section a wide interpretation in order to ensure its effectiveness. I hesitate therefore to restrict the term "proceedings" to those necessarily involving a court or court official because there are situations in which to do so would allow non-judicial proceedings to go against the creditor which would effectively prejudice other creditors and make effective arrangement impossible. The restriction could thus defeat the purpose of the Act.

As a result, in the absence of a clear indication from Parliament of an intention to restrict "proceedings" to "proceedings which involve either a court or court official", I cannot find that the term should be so restricted. Had Parliament intended to so restrict the term, it would have been easy to qualify it by saying for instance "proceedings before a court or tribunal".

The approach taken by Mr. Justice Wachowich is consistent with the policy of the $C C A A$ as outlined above. A narrow interpretation would serve to unduly frustrate the stated purpose of the $C C A A$. If secured creditors were allowed to strip assets from the corporation, arrangements would rarely be successfully implemented.

This issue was raised in a recent decision of the B.C. Court of Appeal in Northland Properties Ltd. v. Guardian Trust Company. ${ }^{31}$ In the B.C. Supreme Court, Mr. Justice Trainor ruled against arguments that the words "suit, action or other proceeding" do not encompass a realization upon an assignment of rents or an assignment of book debts granted in favour of a creditor. In an application for leave to appeal this order however, Hutcheon, J.A. of the B.C. Court of Appeal expressed doubts that these extra-judicial realizations were contemplated within the wording of s. 11, although he did not decide the issue.

Ronald N. Robertson, Q.C., in his article "Legal Problems on Reorganization of Major Financial \& Commercial Debtors", ${ }^{32}$ refers to the wide approach as "a purposive interpretation" of the CCAA. He states at page 15 of his article:

This purposive interpretation of the word "proceeding" is supported by the interpretation of the word used in a similar provision of the Winding-Up Act. It was held in the case Re Winnipeg v. Western Development Company (1916), 9 W.W.R. 1360 that a sale of land by mortgagees under a power of sale is a "proceeding" within the meaning of the Winding-Up Act, although it should be noted that a contrary interpretation was given in the case in Re B.C. Tie and Lumber Company (1908) 14 B.C.R. 81 where it was held that the action of mortgagees in possession proceeding to sell security under the powers in the mortgage was not a "proceeding" within the meaning of the Winding-Up Act. There are also decisions giving the word "proceeding" a broad meaning under the Mortgage Act and the Limitations Act of Ontario. In Smith v. Brown (1890) 20 O.R. 165 it was held that an advertisement to sell lands under a power of sale was a "proceeding" within the meaning of the words "no further proceedings" in s. 30 of the Mortgages Act and thus was prohibited by that section. In Neil v. Almond (1897) 29 O.R. 63, the same judge held that a "proceeding" was "an act necessary to be done in order to obtain a given end; it is a prescribed mode of action for carrying into effect a legal right" and that the taking of steps to sell property under a writ of $f$ i fa is a "proceeding" for purposes of the Limitation Act.

The second question raised above is somewhat more controversial. The issue as to whether courts have the power under the $C C A A$ to restrain parties that are not

30. Supra, note 27.

31. Unreported, 25 July 1988, Vancouver Registry, C.A. 009605 (B.C.C.A.).

32. (1983), Canadian Bar Association - Ontario Continuing Legal Education. 
creditors from taking action against the debtor corporation has arisen on more than one occasion. In the case Re Nathan Feifer v. Frame Manufacturing Corporation $^{33}$ the Quebec Court of Appeal ruled that a landlord was restrained from evicting the debtor corporation from its leased premises. The lease contained a provision which stated that the lease would be null and void if the tenant became insolvent or bankrupt. The court was of the opinion that permitting the landlord to rely on the contractual provisions contained within the lease would, in effect, render the $C C A A$ useless. In order to give full effect to the $C C A A$ the court felt that it was necessary to restrain actions which would effectively prejudice the corporation's ability to restructure its financial affairs.

This issue came up as well in the Oakwood Petroleums (No. 1) ${ }^{34}$ case. Mr. Justice Forsyth cited with approval the following English translation of a passage from the judgment of St. Germain J. in the Nathan Feifer ${ }^{35}$ case:

In effect, if, on the one hand, one must admit that recourse by a debtor to this law of arrangement constitutes in itself an act of bankruptcy, and if, on the other hand, a termination clause like that which is the subject of the present action permits a lessor to terminate his lease with a lessee, what good is it to the lessee to have recourse to this Act to make an arrangement with its nonsecured creditors, if he must by that very act expose himself to the chance of his lease being terminated?

In the Oakwood Petroleums (No. 1) case, Norcen was seeking to have Oakwood removed as operator of certain oil and gas properties pursuant to the provisions of the Canadian Association of Petroleum Land Men Agreement ("CAPL Agreement") which Oakwood had signed with its joint operators in the subject wells. The CAPL Agreement contained provisions requiring the replacement of an operator which had become insolvent. As indicated above, one of the provisions of the stay order obtained by Oakwood restrained persons having rights under the terms of any operating agreements from taking proceedings to remove Oakwood as operator. Norcen argued that the court had no jurisdiction to include in its stay order such a provision. It argued further that if $\mathrm{s}$. 11 of the $C C A A$ could be interpreted that broadly, then it was unconstitutional in that it purported to affect contractual rights of third parties. Mr. Justice Forsyth rejected Norcen's argument stating at page 91 of his judgment:

Accordingly, if promoting the continuance of insolvent companies is constitutionally valid as insolvency legislation, it follows that a stay which happens to affect some non-creditors in pursuit of that end is valid. Surely a necessary part of promoting the continuance of a company is to give that company some time to stop and gather its faculties without interference from affected parties for a brief period of time. In my opinion the distinction between creditors' contractual rights and the contractual rights of noncreditor third parties that Norcen asks me to draw is not a helpful one in these circumstances. Continuance of a company involves more than consideration of creditor claims. For that reason, I am of the opinion that s. 11 of the $C C A A$ can validly be used to interfere with some other contractual relationships in circumstances which threaten a company's existence.

The effect of a stay preventing joint operators under the CAPL Agreement from taking steps to remove the insolvent operator will probably preclude them from

33. (1947), 28 C.B.R. 124.

34. Supra, note 6.

35. Supra, note 33 at 131 . The official French text reads as follows:

En effet, si, d'un côté, l'on doit admettre que le recours par un débiteur à cette loi d'arrangement, constitue en soi un acte faillite, si, d'un autre côté, une clause résolutoire comme celle qui a fait l'objet du présent litige, permet au locateur de mettre fin au bail de son locataire, à quoi servirait à ce locataire d'avoir recours à la dite loi pour faire un compromis avec ses créanciers non garantis, s'il devait par le fait même s'exposer à voir son ball annulé? 
setting up the insolvency of the operator after the plan is successfully concluded. (Also see the recent case of The Rimoil Corporation v. Hexagon Gas Ltd. , Dynamar Energy Limited and Brannigan Resources Canada Ltd. ${ }^{36}$ ) Upon acceptance of a plan of arrangement the insolvency of the operator ceases and the joint operators who have been stayed will in all likelihood not be able to cannot raise the previous insolvency as a breach.

It seems clear that the evolving principle is that proceedings against the corporation, whether of creditors or non-creditors, will be stayed if in the view of the court they will prejudice the debtor corporation's ability to restructure its financial affairs.

\section{Approval by Creditors}

Assuming the insolvent corporation has managed to stay its creditors and file a plan with the court, the next step is to gauge the support for the plan among the corporation's creditors and shareholders. The issue of classification of creditors for the purpose of voting is considered in Part $V$ of this paper since the principles are common to all arrangement statutes. As indicated, s. 4 and 5 of the $C C A A$ provide for the calling of meetings of the various classes of creditors to vote on the plan of arrangement. Section 6 prescribes voting levels which must be met prior to the debtor corporation taking the next step which is to seek court sanction of the plan. Section 6 reads in part as follows:

Where a majority in number representing three-fourths in value of the creditors, or class of creditors, as the case may be, present and voting either in person or by proxy at the meeting or meetings thereof respectively held pursuant to sections 4 and 5 , or either of such sections, agree to any compromise or arrangement either as proposed or as altered or modified at such meeting or meetings ... .

It is settled law that the section requires only a majority of those present or represented at the meeting to vote in favour of the arrangement if that majority represents three-fourths of the aggregate value of the claims of those creditors present or represented at the meeting. ${ }^{37}$

A question may arise whether the creditors should all vote at a single meeting in their respective classes or whether separate meetings of the respective classes of creditors should be held. English authority has deprecated the practice of holding a single meeting for all classes of creditors. However, in the case Re Wellington Building Corporation Limited ${ }^{88}$ Kingstone J., while refusing to sanction the plan of arrangement for other reasons, indicated that a single meeting will be sufficient if the classes of creditors are properly constituted. It is the writers' view that separate meetings are not required to be called. If classes of creditors or shareholders want separate meetings to discuss the plan they can convene such meetings on their own.

\section{Court Sanction}

Following the requisite approval among the creditors for the proposed plan of arrangement, the next step is for the applicant to convince the court to sanction the plan of arrangement pursuant to the provisions of s. 6 of the $C C A A$. Section 6 reads in part as follows:

36. Unreported, 5 May 1989, J.D. of Calgary, Q.B. $8801-11374$ (Alta. Q.B.).

37. See Re Bilton Brothers Limired (1939), 21 C.B.R. 79 (Ont. S.C.) at 80.

38. (1934), 16 C.B.R. 48 (Ont. S.C.). 
. . . the compromise or arrangement may be sanctioned by the Court, and if so sanctioned is binding on all the creditors, or the class of creditors, as the case may be, and on any trustee for any such class of creditors, whether secured or unsecured, as the case may be, and is also binding on the company, and in the case of a company that has made an authorized assignment or against which a receiving onder has been made under the Bankruptcy Act or is in course of being wound up under the Winding-Up Act, is also binding on the trustee in bankruptcy or liquidator and contributories of the company.

Court sanction of the proposed plan of arrangement does not follow automatically from approval of the plan by the creditors. The proceeding at which the sanction of the court is sought has been termed the "fairness hearing". The duties of the court at the fairness hearing are dealt with in Part VII and are basically the same whether the plan is under the $C C A A$, the $C B C A$ or the $A B C A$. It should be noted that if the plan is rejected for whatever reason, the CCAA (unlike Part III of the Bankruptcy $A c t$ ) does not prescribe automatic bankruptcy. Normally, however, the creditors will exercise all of the remedies available to them.

\section{Appeals}

Section 13 of the $C C A A$ contains the appeal provisions from orders granted under the $C C A A$. It provides that "any person dissatisfied with an order or decision made under this Act may appeal therefrom upon obtaining leave . . ." Leave may be sought from three sources. These are:

(1) the judge appealed from;

(2) a judge of the court appealed to; or

(3) the court to which an appeal lies.

The purpose of a leave requirement is to prevent frivolous and unnecessary appeals. ${ }^{39}$ This is particularly important in $C C A A$ applications where a dissatisfied party may resort to the appeal process to delay the implementation of the plan, perhaps ultimately frustrating the plan by virtue of such delay.

Granting of leave to appeal is discretionary on the part of the judge seized with the issue. However, this discretion must be exercised on a proper basis. There are numerous cases that set out the principles which the court should apply in order to properly exercise such discretion. The key is whether or not the appeal raises arguable issues of sufficient substance and importance to be considered by the appellate court. Generally speaking, absent other factors such as inordinate delay by the appellant ${ }^{40}$ or where the issues have become academic to the parties concerned, ${ }^{41}$ the court will grant leave if it is shown that the party has an arguable case on the merits. However, leave will not be granted in every case where there exists an arguable point unless the matter is of sufficient importance to the rights of the respective parties to warrant it. ${ }^{42}$ There is no need for the judge seized with

39. Re Smith \& Hogan, Limited, Industrial Acceptance Corporation Limired and Canadian Acceptance Corporation Ltd. v. The Canada Permanent Trust Company, [1931] S.C.R. 652. See also Lane v. Esdaile, [1891] A.C. 210; Ernewein v. Minister of Employment \& Immigration (1980), 14 C.P.C. 264 (S.C.C.); Western Securities Lid. v. Foothills and Whycom Holdings Ldd., [1982] 1 W.W.R. 171 (Alta. C.A.).

40. See United Services Funds v. Richardson Greenshields of Canada Limired/Richardson Greenshields Du Canada Limitee (1988), 18 B.C.L.R. (2d) 367 (B.C.C.A.).

41. See Yorkshire Trust Company v. City West Management Corporation (1988), 19 B.C.L.R. (2d) 57 (B.C.C.A.).

42. Royal Bank of Canada v. Astro Hotel Lsd. (1986), 70 B.C.L.R. 77 (B.C.C.A.). 
the issue to be convinced of the merits of the appeal as long as there are substantial questions to be argued. ${ }^{43}$ It is therefore not necessary that the judge from whom leave is sought be persuaded that the decision appealed from is "probably wrong" since this would duplicate the function of the appeal court and would invariably require full advance argument of the appeal on the leave application. ${ }^{44}$

In the Oakwood Petroleums case the Hong Kong Bank of Canada sought leave to appeal the decision of Mr. Justice Forsyth on the issue of classification of creditors. Mr. Justice Forsyth refused leave to appeal on the basis that an appeal at that stage of the proceedings would have caused delay and might have resulted in the frustration of the plan of arrangement. ${ }^{45} \mathrm{Mr}$. Justice Forsyth made this decision despite acknowledging the merits and substantive importance of the issues raised. It is arguable that this was not a proper exercise of the discretion granted under the $C C A A$ as the decision to refuse leave was not made on the acknowledged merits of the appeal. However, while Justice Forsyth refused leave to appeal his preliminary directions on classification, he left open the possibility of parties appealing any of his rulings following the fairness hearing.

A danger of seeking leave to appeal from the judge who made the ruling is that having heard the whole case he may refuse leave, being satisfied that his decision is correct and that an appeal is without merit. There are many cases where it has been held that there is no appeal from a denial of leave by the judge appealed from or by an appellate judge. Nor will a new leave application be heard by an appellate court. In Western Securities Ltd. v. Foothills and Whycom Holdings Ltd. ${ }^{46}$ Kerans J.A. states: "In my view the governing rule is that a leave denial is final for all purposes." Citing the Ernewein ${ }^{47}$ case Kerans J.A. states at page 173 that "the rationale of Ernewein is that a right of appeal from a leave denial is antithetical to the idea of leave". Again at page 173 he states:

Surely if that is intended as a check to unnecessary or frivolous appeals it becomes absolutely illusory if you can appeal from that decision or leave or whatever it is to be called itself.

It appears therefore, that there is no appeal from a denial of leave where that decision is based on a full hearing on the merits of the application.$^{48}$ However, where there is a refusal by the court to consider the application on its merits it is arguable that there has not been a proper exercise of jurisdiction and the appellant may still be entitled to a new hearing on the merits of his application. Cartwright $\mathrm{J}$. in the case Canadian Utilities Limited and Western Chemicals Limited v. Deputy Minister of National Revenue for Customs and Excise ${ }^{49}$ states:

It appears to me to have been consistently held in our courts and in the courts of England that where a statute grants a right of appeal conditionally upon leave to appeal being granted by a specified tribunal there is no appeal from the decision of that tribunal to refuse leave, provided that the tribunal has not mistakenly declined jurisdiction but has reached a decision on the merits of the application.

The same view was expressed by Laskin C.J.C. speaking for the majority of the Supreme Court of Canada in the Ernewein case. ${ }^{50}$

43. Re Shingoose v. Min. of Social Services, [1983] 4 D.L.R. (4th) 765 (Sask. C.A.).

44. Canadian Egg Marketing Agency v. Sunnylea Foods Lid. (1977), 3 C.P.C. 348 (Ont. S.C.).

45. Unreported, 22 December 1988, J.D. of Calgary, Q.B. $8801-1445$ (Alta. Q.B.).

46. Supra, note 39 at 172.

47. Supra, note 39.

48. In Re Smith \& Hogan, supra, note 39.

49. [1964] S.C.R. 57 at 63.

50. Supra, note 39. 


\section{Procedure on Appeal}

Section 14 of the $C C A A$ states that no appeal shall be entertained unless within 21 days from the rendering of the order or decision appealed from the appellant has taken proceedings to perfect his appeal. Section 14 also grants the court the discretion to extend this period. However, in Gaz Metropolitan v. Wynden Canada Inc. ${ }^{51}$ the Quebec Court of Appeal per Bisson J.A. decided that after the expiry of the 21 day period only the court which originally rendered the judgment appealed from has the jurisdiction to extend the time for appeal. The procedures that should be followed are the standard appeal procedures set out in the Rules of Court.

\section{REORGANIZATIONS UNDER THE BUSINESS CORPORATION ACTS}

Part XV of the $C B C A$ and Part 15 of the $A B C A$ deal with corporate reorganizations and arrangements. These parts deal with amendments to the articles of a corporation, amalgamations, reorganizations and arrangements.

\section{A. THE CANADA BUSINESS CORPORATIONS ACT - PART XV}

\section{Section 191}

Section 191 of the $C B C A$ concerns "reorganizations" as defined in the section. This section may be used to assist a reorganization of an insolvent corporation under the Bankruptcy Act or CCAA.

Under the $C C A A$ the court may order meetings of creditors and shareholders (ss. 4 and 5). However, unlike in the case of creditors, the $C C A A$ contains no provision whereunder the shareholders may vote on the proposed plan such that the result will be binding on all of them. Often a reorganization under the $C C A A$ requires dramatic changes to the share structure of the insolvent corporation. Section 191 may be used to give effect to arrangements under the $C C A A$ which affect the shares of the corporation. Section 191 provides, inter alia, that where a corporation is subject to a court order under s. 241 of the $C B C A$ (the oppression remedy section) or under the Bankruptcy Act approving a proposal, or any other Act of Parliament that affects the rights among the corporation, its shareholders and creditors (e.g. the $C C A A$ ), its articles may be amended by such order as the court deems necessary to effect any change that might lawfully be made by an amendment under $\mathrm{s} .173$ of the $C B C A$. Section 173 deals with amendments to a corporation's articles including its share structure. Therefore, once an order has been made under the Bankruptcy Act approving a proposal or under the $C C A A$ the court can alter the share structure of the corporation. Section 191(7) provides that a shareholder is not entitled to dissent under s. 190 and demand payment of "fair value" for his shares. The very definition of "reorganization" within s. 191 encompasses corporate reorganizations that are made under insolvency statutes where generally the shares do not have value. 


\section{Section 192}

Section 192 of the $C B C A$ deals with "arrangements" where an applicant that is not insolvent wishes to effect a fundamental change to its corporate structure. Section 192 is a relatively new section of the $C B C A$, inserted by way of amendment to the $C B C A$ in $1978 . .^{52}$ Prior to that time the $C B C A$ did not have any provision within the scope of $s .192$ permitting the reorganization of one or more corporations' affairs involving many steps and types of securities within one plan and one procedure. It was this section that was utilized to accomplish the mammoth reorganization and acquisition of Dome by Amoco Canada.

Section 192(1) of the $C B C A$ was formerly s. 185.1 prior to the proclamation of the Revised Statutes of Canada 1985 on December 12, 1988. Throughout this paper reference is made to $\mathrm{s}$. 192. However, where judicial decisions are cited, references therein to $\mathrm{s} .185 .1$ have not been changed.

Section 192 of the $C B C A$ defines "arrangement" to include:

(a) an amendment to the articles of a corporation;

(b) an amalgamation of two or more corporations;

(c) an amalgamation of a body corporate with a corporation that results in an amalgamated corporation subject to this Act;

(d) a division of the business carried on by a corporation;

(e) a transfer of all or substantially all the property of a corporation to another body corporate in exchange for property, money or securities of the body corporate;

(f) an exchange of securities of a corporation held by security holders for property, money or other securities of the corporation or property, money or securities of another body corporate that is not a takeover bid as defined in s. 194;

(g) a liquidation and dissolution of a corporation; and

(h) any combination of the foregoing.

At common law the term "arrangement" was given a very wide character. ${ }^{53} \mathrm{Sec}-$ tion 192 has not restricted the broad character of "arrangements".

Section 192(3) states:

Where it is not practicable for a corporation that is not insolvent to effect a fundamental change in the nature of an arrangement under any other provision of this Act, the corporation may apply to a court for an order approving an arrangement proposed by the corporation. (emphasis added)

Therefore, s. 192(3) sets out four criteria for an order of the court to be granted:

(1) the applicant must be a corporation. A corporation is defined in $\mathbf{s} .2$ of the $C B C A$ as "a body corporate incorporated or continued under this Act and not discontinued under this Act".

(2) the applicant must not be insolvent as defined in s. 192(2). Section 192(2) provides that "for the purposes of this section a corporation is insolvent where it is unable to pay its liabilities as they become due or where the realizable value of the assets of the corporation are less than the aggregate of its liabilities and stated capital of all classes."

52. An Act to Amend the Canada Business Corporations Act, S.C. 1978-79, c.9, s. 61.

53. Re West Humber Apartments Lid. (1969), 2 DLR (3d) 110 (Ont. H.C.); Re: English, Scotrish and Australian Chartered Bank (1893), 3 Ch. 385; (1891-4) All E.R. 775; L.C.B. Gower, Modem Company Law (4th ed. 1979) 687. 
(3) it must not be practicable to effect the fundamental change in the nature of an arrangement under any other provision of the $C B C A$.

(4) a plan of arrangement must effect a fundamental change in the nature of an arrangement.

The judicial interpretation of the words "not practicable" in criterion 3 above makes it abundantly clear that it is not necessary to find that the transaction would otherwise be impossible under other provisions of the $C B C A$. It is sufficient to establish that it would be difficult, or not practical, to implement the plan of arrangement other than pursuant to s. $192 . .^{54}$

Section 192(4) arms the court with the right to make any interim or final order it thinks fit when an application is made to approve an arrangement, including an order determining the notice to be given to any interested person or dispensing with notice to any person other than the Director under the $C B C A$, an order appointing counsel at the expense of the corporation to represent the interests of shareholders; an order requiring $a$ corporation to call, hold and conduct a meeting of holders of securities or options or rights to acquire securities in such manner as the court directs; an order permitting a shareholder to dissent under s. 190 and an order approving an arrangement as proposed by the corporation or as amended in any manner that the court may direct.

It is immediately apparent that s. 192(4) provides the court with substantial powers and discretion in considering a plan or arrangement. The court may order meetings of shareholders and creditors of a corporation which may not necessarily be the applicant but it does not have to. The subsection does not stipulate mandatory voting levels at meetings ordered by the court. The court may approve the arrangements as proposed or as amended in any manner as it may direct. The court is clearly in charge. It determines the "faimess" of the plan of arrangement. If it doesn't approve of the arrangement in toto it can amend it.

Upon approval by the court, articles of arrangement in a prescribed form must be sent to the Director under the $C B C A$ whereupon the Director will issue a certificate of amendment. The arrangement becomes effective on the date shown in the certificate of amendment.

In the acquisition of Dome by Amoco Canada, s. 192 alone was used, without resort to any insolvency statute, to effect a massive restructuring of debt and a compulsory exchange of Dome voting shares for debt instruments of Amoco Canada thereby affecting a change of ownership of Dome.

\section{(a) The Dome/Amoco Canada Arrangement}

Under s. 192 even though Dome was ultimately found to be insolvent, Amoco was not and therefore s. 192 could be utilized. Amoco Canada and Dome signed a memorandum of agreement whereby Amoco Canada agreed with Dome to enter into an arrangement (the "Arrangement Agreement") providing for the acquisition by Amoco Canada of all the right, title and interest of various creditors of Dome and its subsidiaries in and to certain defined credit facilities (the "Affected Credit Facilities') and providing that all the outstanding equity of Dome would be

54. Imperial Trust Co. and Taylor Assets (Dominion) Lsd. v. Canbra Foods Lid. (1987) 78 A.R. 267 (Alta. Q.B.); B. Love Lid. v. Bulk Steel \& Salvage Ldd. (1982), 137 D.L.R. (3d) 602; Re: El Sombrero Lid., [1958] 3 All E.R. 1 (Ch.D). 
exchanged for certain securities of Amoco Canada. Pursuant to the Arrangement Agreement, Amoco Canada agreed to proceed with an application for an order under s. 192 of the $C B C A$ approving a plan of arrangement (the "Plan of Arrangement'). The Arrangement Agreement, as amended, further provided that a subsidiary of Amoco Canada (defined to include a subsidiary of a subsidiary) could make the court application for approval. The application was made by a company called Amoco Acquisition Company Ltd. ("Amoco Acquisition").

The Plan of Arrangement was extremely complex. A series of twenty-one events were scheduled to occur in sequence, one event immediately following the other. It was absolutely essential that none of the events was effective unless all were effective. While there were twenty-one events scheduled to occur under the Plan of Arrangement there were three major aspects of the Plan:

(1) The amalgamation of Dome and certain of its subsidiaries into a short lived entity called Amalco No. 1.

(2) The sale, assignment and transfer to Amoco Canada of the interests of the creditors under the Affected Credit Facilities and the indebtedness thereunder in exchange for cash and/or newly issued debt securities of Amoco Canada, and the conversion of such indebtedness by Amoco Canada into equity of a Dome subsidiary called Dome Energy Limited and Amalco No. 1.

(3) The amalgamation of Amoco Acquisition with Amalco No. 1 and a Dome subsidiary into Amalco No. 2. Prior thereto, Amoco Acquisition acquired debt instruments entitled "Subordinated Exchangeable Debentures"' ('SEDs") of Amoco Canada and as a result of this amalgamation Amalco No. 2 held the SEDs. The shares of Dome held by the public and other investors on the amalgamation were converted into Class X Redeemable Preferred Shares of Amalco No. 2. The Class X Shares were redeemed in accordance with their terms for SEDs.

The corporate structure after the completion of the plan resulted in Amoco Canada owning $100 \%$ of the shares of a company called Amoco Holdings; Amoco Holdings owned $100 \%$ of the shares of Amalco No. 2 which continued under the name of Dome Petroleum Limited; former Dome shareholders held SEDs of Amoco Canada; and former creditors under the Affected Credit Facilities had cash and/or newly issued debt securities of Amoco Canada.

The Court of Appeal of Alberta described the Plan of Arrangement as follows: ${ }^{55}$

This proposal is immensely complicated, and involves the restructuring of several billion dollars in secured debts . . ., as well as all the outstanding shares in Dome. If approved, the result will be that the legal entity that once was Dome will survive as a wholly owned subsidiary, through intermediary corporations, of Amoco Canada Petroleum Company Ltd. The secured debt will be compromised at $95 \%$ of face value and the unsecured debt at $45 \%$ (or thereabouts), and these compromised obligations will then be paid or secured by Amoco. Part of the proposal is that each shareholder in Dome, whether preferred or common, will lose his shares but receive some debentures from a fund or group of debentures with a total face value of $\$ 439$ million. This price, if that is the appropriate word, represents a very small fraction of the shareholder investment.

A very important aspect of the Plan of Arrangement was that Dome shareholders, both common and preferred, were to share in a fund valued at $\$ 439$ million. The shares of Dome were divided into preferred and common. The preferred shares represented a very small percentage of the total issued share capital. Dome had never 
paid a dividend to common shareholders and since June 1, 1986 had not been in a position to pay dividends on its preferred shares. The evaluation of both preferred and common shares for purposes of compensation under the Plan of Arrangement was carried out on an identical basis, that is, the average trading price for the twenty days prior to the announcement of the Arrangement Agreement. The compensation to common and preferred shareholders from the fund was payable in the form of SEDs, with each common share to receive approximately U.S. \$1.13 principal amount of SEDs and each preferred share to receive U.S. \$5.60 principal amount of SEDs.

The applicant under s. 192 of the $C B C A$ was not Dome but rather Amoco Acquisition. There was no doubt that Dome was insolvent.

It is important to appreciate that the Plan of Arrangement proceeded through the courts without a challenge from any creditor, either secured or unsecured. The objectors were all shareholders.

While the plain wording of s. 192 would permit the application to succeed, the section had not been tested in the manner contemplated by the Plan of Arrangement. The purpose and scope of s. 192 was in some doubt. Although much of Canadian company legislation has evolved from the English statutes, and while the English statutes clearly authorize arrangements that compromise debt, the question had to be determined as to whether s. 192, as opposed to the $C C A A$, could be used to this end. Those portions of English corporate legislation dealing with reorganization of insolvent corporations, such as contained in s. 153 of the English Companies Act, had been placed not in the federal corporations statutes but in the $C C A A$. Furthermore, while Dome was the company being reorganized it was insolvent and could not be the applicant.

In order to avoid the possibility that at the end of lengthy and costly proceedings under the $C B C A$ a court, perhaps the Supreme Court of Canada, could conclude that s. 192 of the $C B C A$ could not be utilized to effect the Plan of Arrangement, it was determined that a preliminary application would be pursued, on notice to all creditors and shareholders, seeking declarations that the Arrangement Agreement was an arrangement within s. 192 of the $C B C A$; that the Court of Queen's Bench of Alberta had jurisdiction to approve the Plan of Arrangement; and that the final order approving the Arrangement, if granted, would be binding on the non-assenting creditors and shareholders of Dome and its subsidiaries.

The preliminary application also sought directions on the classification of shareholders and creditors of Dome and its subsidiaries for the purpose of voting on the Plan of Arrangement, the voting levels for each class and the calling and holding of such meetings as were required by the court.

The preliminary application for the declarations and directions was heard before Justice Forsyth in January, 1988. The main opposition came from a preferred shareholder and from a number of common shareholders of Dome. The shareholders argued that Amoco Acquisition was not the proper party to make the application and that the insolvent Dome could not. They further argued that the "impracticability" requirement for using s. 192 had not been met, and that the application was really a take-over bid under Part XVI of the $C B C A$ and therefore the contemplated exchange of securities could not take place under s.192(1)(f). Further, the preferred shareholders argued that they were entitled to a separate voting class. In any event, 
they argued, they should receive payment in full for their shares from the fund of $\$ 439$ million as the Plan of Arrangement was tantamount to a liquidation and at law the preferred shares were entitled to a liquidation preference.

Justice Forsyth's reasons on the preliminary matters were in two installments. On January 27,1988 he dealt with the jurisdiction of the court to hear the application unders. 192 of the $C B C A$, the impracticability test, and the argument that the arrangement was in effect a takeover bid. At page 2 of his Reasons for Decision (unreported) Justice Forsyth stated as follows:

After consideration of all of these arguments, I am satisfied that the applicant, Amoco Acquisition Company Limited - which I shall refer to as Amoco Acquisition - is properly before this court. This is clearly, on the evidence, not a sham application being made indirectly by an insolvent company through a route designed to circumvent the solvency requirements of sub-section 3 of s. 185.1 of the Act.

Section 185.1(1) of the Act clearly contemplates arrangements involving more than one corporation. The language of subs. 3 is clear in stating that a corporation making the application must be solvent. Amoco Acquisition, as one of the corporations involved in the proposed arrangement, is solvent and accordingly is entitled to make this application.

I am also satisfied that Amoco Acquisition has met the requirement that it is impracticable to effect the fundamental changes contemplated under any provisions of the $C B C A$, and accordingly Amoco Acquisition has met the requirement.

In dealing with the arrangement section of the $C B C A$ Justice Forsyth made the following important comments about its scope:

Section 185 of that Act allows for flexibility and indeed ingenuity in corporations devising arrangements required to meet complex and changing business situations. Recognizing that such proposed arrangements may well impact upon shareholders and creditors of such corporations, Parliament has provided the court with very broad powers with respect to any such proposed arrangements which bring into play the court considering the faimess of such arrangements to all parties effected.

Justice Forsyth then declared that the Plan of Arrangement was an arrangement within the meaning of s. 192 of the $C B C A$ and that the court had jurisdiction to approve the plan. The court interpreted s. 192 of the $C B C A$ as giving it "very broad powers" in determining the "fairness of such arrangement to all parties effected". The Alberta Court of Queen's Bench and Court of Appeal throughout the Amoco Canada/Dome Plan of Arrangement stressed the "uniqueness" and complexity of the plan.

Having found that the plan was within s. 192 of the $C B C A$ and that there was no other practicable way to accomplish the reorganization, Justice Forsyth on January 28, 1988 gave directions as to the grouping of creditors and shareholders. These directions, which were upheld by the Court of Appeal, show the extent to which the court was prepared to go to ensure that the plan would not be scuttled by any one small group. At page 3 of his January 29, 1988 Reasons for Decision (unreported) Justice Forsyth states as follows:

All counsel appear to concede that the proposed arrangement in this matter is unique. That uniqueness
must be illustrated before ruling on the dispositions I propose to make. The arrangement involves secured
creditors agreeing to receive approximately $\$ .95$ on the dollar on their secured debt. The unsecured
creditors will receive approximately $\$ .45$ for each dollar of debt. This proposed settlement with creditors
represents a shortfall of approximately $\$ 998$ million U.S. to creditors, both secured and ordinary.
An equity fund of some $\$ 439$ million has been established for the benefit of shareholders, both com-
mon and preferred. That fund does not involve paying cash to the shareholders but rather the share-
holders will ultimately receive what are referred to as Subordinated Exchangeable Debentures.
Financial statements of Dome in evidence before me coupled with the fact that the market was tested
and the Amoco proposal was accepted by the Board of Dome as the most favourable lends credence
to the view that there is no equity, in the conventional sense, in Dome at this time and that in the event
of a liquidation the shareholders would receive nothing. However as this arrangement is structured, 
there is apparently value in the acquiring shares of Dome rather than proceeding simply on a purchase of assets.

By the date of the application Amoco Canada had agreed with the secured lenders that each of their credit facilities would constitute a separate class. No meetings were necessary as the secured creditors would execute consents. In dealing with a number of unsecured creditors consisting primarily of financial institutions Justice Forsyth accepted the proposal of the applicant as to how the group would vote as no objection was raised by any party in the group.

In dealing with the large public unsecured group consisting of certain creditors spread throughout Europe, Justice Forsyth established a procedure that would enable the court to assess certain negative votes to the plan without establishing separate classes. He ordered that certain Eurodollar facilities' votes be tabulated separately although they were to be included in the larger public unsecured class. He did the same with the preferred shareholders:

Representations were heard from counsel and individuals representing common shares and from counsel representing some Class " $A$ " and " $B$ " preferred shares. The arguments advanced and the case law submitted clearly established that in the usual ordinary circumstances where classes are being established preferred and common shares, because of their differing characteristics, should be treated as separate classes. But this is not, in my judgement, a situation where that differentiation is either necessary or desirable.

To establish a separate class for the preferred shareholders would give to a very small minority group near the bottom of the chain of priorities in a vast and troubled corporation a virtual veto over its attempts to extricate itself from its difficulties. It would, as one counsel suggests, introduce the tyranny of the minority. I am satisfied that under the circumstances of this case, as I have outlined them, one class of shareholders only should be established. However, as in the case of the public secured debt, I direct that a separate tabulation of the preferred shares as contrast to common be maintained.

The "separate tabulation" mechanism enabled the judge to assess the degree of opposition among the preferred shareholders without providing them with "a virtual veto" over the attempts of Dome to extricate itself from its financial difficulties. In dismissing the argument concerning the liquidation preference Justice Forsyth merely held that the plan was not a liquidation. It was an arrangement that recognized the respective values of preferred versus common shares in a manner that appeared appropriate under all the circumstances. Further Justice Forsyth rejected the argument that the arrangement was a "takeover bid". Although the results of the arrangement in some respects resembled a takeover bid it was not one because there was no offer to shareholders. The indicia of a takeover bid were not present.

Justice Forsyth recognized that some shareholders "with optimistic view points may have the view that there is equity in Dome and that the amount proposed to be paid into the equity fund is not sufficient"'. Accordingly he exercised his jurisdiction under s. 192(4)(b) of the $C B C A$ by granting the right for shareholders to dissent. However, any successful dissent resulting in the purchase of shares for fair value would only be paid in SEDs not cash. Justice Forsyth reasoned that to allow dissenting shareholders to be paid in cash would strike at the heart of the arrangement entered into between the parties, including creditors, and would introduce a degree of unfairness to creditors and other shareholders.

The Orders of Justice Forsyth were appealed. The Court of Appeal rendered its decision from the bench on April 19, 1988. ${ }^{56} \mathrm{Kerans}$ J.A., speaking for the court dealt with the arrangement section of the $C B C A$ : 
The interim application, the results of which have been appealed to us, was brought pursuant to s.185.1 (4)(c). The result of the order on the interim application is that, when the matter comes before the court for approval, the views of several groups of creditors and shareholders will have been canvassed. We emphasize, however, that, unlike a takeover or an amalgamation, "an arrangement", strictly speaking, can be approved by the court without the known views of these groups, or indeed, despite them. We hasten to add that the clear duty of a court is not to approve an arrangement that is unfair to any interested party, and, almost always, the approval or disapproval of creditors or shareholders would bear on that process.

The Court of Appeal affirmed the extremely wide latitude that the court has in considering the faimess of an arrangement under the $C B C A$. It is easily recognized that $\mathrm{s} .192$ of the $C B C A$ can become a powerful weapon in the arsenal of corporate counsel wishing to restructure a financially troubled corporation. Unlike the $C C A A$, Part III of the Bankruptcy Act, or the arrangement sections of the $A B C A$ all of which contain mandatory classification and voting requirements, s. 192 does not. The judge is the sole arbiter of what is fair. While the court will consider the views of the several groups of creditors and shareholders, it is not bound by a negative reaction from any interested party.

In dealing with the arrangement itself Kerans J.A., stated as follows at pages 263-264:

In our view, the key to the case is this: this arrangement indeed involves what might be called an indirect takeover, but it is more than a mere offer to acquire shares; it involves amalgamation but is more than an amalgamation; it involves the compromise of debt but it is more than that. Its very complexity lifts it out of any of these categories. The category of "arrangement" we think exists primarily to deal with proposals that do not quite fit other categories. We are comforted in this view by the fact that the intervenient Director of Corporations for Canada agrees that this proposal is an arrangement within the scope of the section. To give the words of the section the narrow interpretations suggested would defeat that purpose. Accordingly, we say that "exchange" in s. 185.1 includes a compromise, and that the section generally deals with proposals that are much more than a simple offer to acquire the shares of another. So long as a proposal is not a sham, that section is available. This proposal has been found not to be a sham and cogent evidence supports that. Similarly, we would not interpret subs. (3) of the section to limit the section to cases where none of the corporations involved is insolvent which is the effect of the submission of the appellants. Dome may, indeed, be insolvent; but the applicant and others involved are not.

The Court of Appeal has breathed immense life into s. 192 of the $C B C A$. As long as the proposed arrangement is not a sham, the combinations and permutations of amalgamations, property transfers, exchange of securities by way of compromise, and acquisitions, in order to reorganize a financially troubled corporation seem limitless. Further, the court will not be precluded by a veto of a class of creditors or shareholders from considering the fairness of an arrangement. Indeed, in response to the argument that the preferred shareholders should be given their own class which would effectively amount to a veto power of the Plan of Arrangement, the Court of Appeal stated as follows at pages 264-266:

We agree that the basic rule for the creation of groups for the consideration of fundamental corporate changes was expressed by Lord Esher in Sovereign Life Insurance Co. v. Dodd, (1892) 2 Q.B. 573 at 580, when he said, speaking about creditors:

“. . . . if we find a different state of facts existing among different creditors which may differ-

ently affect their minds and their judgements, they must be divided into different classes".

We do not think that this rule justifies the division of shareholders into separate classes on the basis of their presumed prior commitment to a point of view. The state of facts to all is that they are all offered this proposal, face as an altemative the break-up of this apparently insolvent company, and hold shares that appear to be worthless on break-up.

In any event, any attempt to divide them on the basis suggested would be futile. One would have as many groups as there are shareholders. We think that the most that can be done is what the chambers 
judge did. He directed that the vote of majority shareholders with a prior commitment to the applicant be recorded separately, and that either party be at liberty to draw other similar situations to the attention of the approving court. He then can make a fair assessment of the proportion who approve, without any special advantage as well as those with, for whatever insight that may offer to you (sic). We reject this ground ....

Nevertheless, because of this proposal, the judge decided that the shareholders should be consulted and merely said that he would consider a resolution passed by two-thirds of the shareholders. We cannot say that this is unfair. On the contrary, he may have gone too far in offering any advance hint of the conditions under which the court would approve. All counsel concede, however, that he continues at least to have jurisdiction to approve or reject any proposal in the face of any degree of disapproval or approval. We do not quarrel with his attempt to offer some advance indication, but reject the idea that he or we should go further now and we reject this ground of appeal.

Leave to appeal this decision to the Supreme Court of Canada was denied. The message is clear. Unders. 192 the court may approve or reject any proposal in the face of any degree of disapproval or approval. This, of course, leads to the possibility that a court will substitute its own opinion as to what is fair for the opinion of businessmen who have considered and voted on the plan. However, the law as to what a court should consider at a faimess hearing indicates that a court should be reluctant to do this (see Part VIII).

The actual "faimess hearing" took place in June and early July of 1988. On July 14, 1988 Justice Forsyth approved the Plan of Arrangement as being fair. ${ }^{57}$ The Court of Appeal upheld this decision on August 30, 1988. ${ }^{58}$ Leave to appeal to the Supreme Court of Canada was refused.

In assessing the fairness of the Plan of Arrangement Justice Forsyth stated:

The court must be careful not to cater to the special needs of any particular group but must strive to be fair to all that are involved in that transaction depending on the circumstances that exist. . . . In considering the faimess of the transaction, one must not be trapped into considering only the interests of shareholders but must consider the interests of all involved, i.e. secured creditors, preferred creditors (sic) and shareholders both preferred and common.

Justice Forsyth also considered the argument of counsel that notwithstanding the court had previously decided it had jurisdiction to entertain the arrangement the appropriate insolvency legislation should have been used. He stated:

It is to be noted that this is an argument that might more properly, if valid, have been advanced by creditors effected rather than the shareholders. In short, Mr. Stemberg's argument seems to be directed toward the concept that the better protection to creditors lies in the other route suggested rather than in this route. In the absence of any evidence whatsoever suggesting that somehow their rights have been abused by this process, I fail to see that any credence can be given to this argument.

It may be that in future applications under s. 192 a creditor will successfully argue that it is entitled to have the protection of fixed voting classes with compulsory voting levels as required by other legislation. A judge may hold that the Amoco Canada/Dome arrangement was the unique case that the Alberta courts said it was and that future applicants attempting to compromise debt should use the more stringent insolvency statutes, or at least be bound by the same requirement for classes and fixed threshold voting levels as contained in the insolvency legislation.

\section{B. THE ALBERTA BUSINESS CORPORATIONS ACT - PART 15}

\section{Section 185}

Section 185(1) of the $A B C A$ is similar in scope to s. 191 of the $C B C A$. It deals with reorganizations where there has been a court order under the "oppression"

57. Unreported, 14 July 1988 J.D. of Calgary Q.B. $8701-20108$ (Alta. Q.B.).

58. (1988), 61 Alta. L.R. (2d) 279. 
section of the $A B C A$ (s. 234), an order approving a proposal under the Bankruptcy $A C t$, or an order under any Act of Parliament. (e.g. the $C C A A$ ) or of the legislature that affects the rights among the corporation, its shareholders and creditors.

Section 185(2) states that if the corporation is subject to an order for reorganization its articles may be amended by an order to effect any change that might lawfully be made by an amendment to the articles of the corporation under section 167 . Subsection 185(3) provides that if the court makes an order for reorganization it may also authorize the issue of debt obligations of the corporation, whether or not convertible into shares of any class or having attached any rights or options to acquire shares of any class, and fix the terms of those debt obligations and appoint directors in place of or in addition to all or any of the directors then in office.

Section 185 , like its counterpart in the $C B C A$, is primarily intended to apply where a corporation is bankrupt or insolvent. Its constitutionality, however, may be suspect as the federal government has exclusive jurisdiction over bankruptcy and insolvency. It is doubtful that the $A B C A$ can constitutionally add to the provisions of the Bankruptcy Act or the CCAA.

\section{Section 186}

At first glance section 186 of the $A B C A$, which deals with court approved arrangements, appears to be very similar to section 192 of the $C B C A$. However, there are some significant differences, which in light of the Alberta Court of Appeal's decision in the Savage v. Amoco Acquisition Company Ltd. case ${ }^{59}$ show the arrangement provisions of the $A B C A$ to be considerably less flexible than those of the $C B C A$.

The provision dealing with who may apply for a court approved arrangement is wider in the $A B C A$ than in the $C B C A$. An application may be made to the court by a corporation or a security holder or creditor of a corporation for an order approving an arrangement. There is no provision in the $A B C A$ requiring the applicant to be solvent while under the $C B C A$ only a corporation that is solvent may apply.

The definition of arrangement under section $186(1)$ of the $A B C A$, like its $C B C A$ counterpart, is extremely wide. The definition states that arrangement "includes but is not restricted to" a list which is similar to the list contained in section 192 of the $C B C A$. There is one specific addition. Section 186(1)(h) states that an arrangement includes:

a compromise between a corporation and its creditors or any class of its creditors or between a corporation and the holders of its shares or debt obligations or any class of those holders.

The $A B C A$ specifically purports to allow compromise of debt. It is not our intention to deal with the constitutionality of this section but as pointed out above the federal government has exclusive jurisdiction to legislate over bankruptcy and insolvency. If an insolvent Alberta corporation attempts to use section 186 to reorganize and compromise its debt, a non-assenting creditor may challenge the constitutional validity of subsection (h) and subsection (f) (which deals with an exchange of securities) if these sections have the effect of forcing it to accept anything less than the full value of its claim. 
Once an application is made under section 186 of the $A B C A$ there are some fundamental differences in the powers of the court considering the arrangement. Unless the court dismisses the application upon its filing, subs. 4 states that it shall order the holding of a meeting of shareholders or a class or classes of shareholders to vote on the proposed arrangement; shall order a meeting of persons who are creditors or holders of debt obligations of the corporation or of options or rights to acquire securities of the corporation, or any class of those persons if the court considers that those persons or the class of persons are affected; and may give directions regarding the calling and conducting of the meetings. Meetings of creditors and shareholders are compulsory.

Section 186(6) provides that any order of the court respecting the majority required to pass a resolution at the meetings so called shall not provide for a majority that is less than the following:

(a) in the case of a vote of the shareholders or a class of shareholders, a majority of at least $2 / 3$ of the votes cast by the shareholders voting on the resolution;

(b) in the case of a vote of creditors or class of creditors, a majority in number representing at least $2 / 3$ of the amount of their claims; and,

(c) in the case of a vote of the holders of debt obligations or a class of those holders, a majority in number representing at least $2 / 3$ of the amount of their claims; and,

(d) in the case of a vote of holders of options or rights to acquire securities, the majority that would be required under clause (a) or (c) if those holders had acquired ownership of the securities.

It is clear from the decision of the Alberta Court of Appeal in the Savage v. Amoco Acquisition Company Ltd. case that the arrangement provisions of the CBCA provide the court with much more flexibility in calling meetings and considering the results of votes than under the $A B C A$. The court is not bound by any legislated voting levels under section 192 of the $C B C A$.

Part 15 of the $A B C A$ was the subject of a paperby Richard A. Shaw entitled "Corporate Reorganization and Arrangements: Part 15 of the Business Corporations Act" ${ }^{60}$ which contains a thorough discussion of the arrangement sections. This paper was cited with approval by Moore C.J. in the case of Imperial Trust Co. \& Taylor Assets (Dominion) Ltd. v. Canbra Foods Ltd. ${ }^{61}$

\section{CLASSIFICATION OF CREDITORS AND SHAREHOLDERS}

The statutes discussed above, the $C C A A, C B C A, A B C A$ and Part III of the Bankruptcy Act all contemplate that creditors (and where applicable, shareholders) will vote in classes. The leading case on classification is Sovereign Life Assurance v. Dodd, ${ }^{62}$ which had under consideration the arrangement provisions of the English Joint Stock Companies Arrangement Act, 1870 from which the CCAA was derived. Esher L.J. stated at 249:

The Act provides that the persons to be summoned to the meeting, all of whom, it is to be observed, are creditors, are persons who can be divided into different classes, classes which the Act recognizes, although it does not define. The creditors, therefore, must be divided into different classes.

60. (Alberta) Legal Education Society of Alberta - Banff Refresher Course. Corporate Commercial Law - 1986.

61. Supra, note 54.

62. [1891-94] All E.R. 246. 
The Sovereign Life case has been accepted as a leading case on classification of creditors in numerous Canadian cases. ${ }^{63}$

Where the holding of meetings of classes of shareholders and creditors is required, the question becomes what principles apply to the setting of classes. Kerans J.A. of the Alberta Court of Appeal in Savage v. Amoco Acquisition Co. Ltd. ${ }^{64}$ stated:

We agree that the basic rule for the creation of groups for the consideration of fundamental corporate changes was expressed by Lord Esher in Sovereign Life Assurance Co. v. Dodd [1892] 2 Q.B. 573 at 580 when he said, speaking about creditors:

“. . . if we find a different state of facts existing among different creditors which may differently affect their minds and their judgements, they must be divided into different classes."

There is clear recognition that both shareholders and creditors of a corporation may have different rights and interests where a corporation is attempting to change its capital structure or reorganize its indebtedness. Classification for voting purposes is the mechanism through which such differences are recognized. The court has a duty to carefully scrutinize the nature of the rights and interests of the shareholders and creditors in the process of establishing a classification scheme in order to ensure that it is only those parties who have similar rights and interests who are grouped into any particular class. In Re Alabama, New Orleans, Texas and Pacific Junction Railway Company ${ }^{65}$ Bowen L.J. states at pp 243-245:

\footnotetext{
Now, I have no doubt at all that it would be improper for the Cour to allow an arrangement to be forced on any class of creditors, if the arrangement cannot reasonably be supposed by sensible business people to be for the benefit of that class as such, otherwise the sanction of the Court would be a sanction to what would be a scheme of confiscation. The object of this section is not confiscation . . . Its object is to enable compromises to be made which are for the common benefit of creditors as creditors, or for the common benefit of some class of creditors as such . . . the Court, which has to see what is reasonable and just as regards the interests of the whole class, would certainly be very much influenced in its decision, if it turned out that the majority was composed of persons who had not really the interests of that class at stake . . . extreme care . . . ought to be brought to bear upon the holding of meetings under it. It enables a compromise to be forced upon the outside creditors by a majority of that class. It would be most unjust to bind creditors or classes of creditors by the decision of three-fourths in value of those who attend a particular meeting, unless you have secured that the meeting shall adequately represent the entire body.
}

The general test which has been applied by the courts in both the cases of shareholders and creditors is that which has been set out in the Sovereign Life $e^{66}$ case at page 53, per Bowen L.J.:

It seems to me that we must give such a meaning to the term "class" as will prevent the section being so worked as to produce confiscation and injustice, and that we must confine its meaning to those persons whose rights are not so dissimilar as to make it impossible for them to consult together with a view to their common interest.

This test is commonly referred to as the "community of interest" test. The case Quebec Steel Products (Industries) Ltd. v. James United Steel ${ }^{67}$ interpreted the requirement of classification under the CCAA in the following way at p. 383:

Although s. 3 does not define the word "class" it would seem that there must be an identity of interest. If so, a meeting of one class of creditors would not affect another class who had a different method of evaluating their position.

63. See Re Wellington, supra, note 38; Re Northland Properties Ldd.; Savage v. Amoco Acquisition Co. Ld., supra, note 55.

64. Supra, note 55 at 42.

65. [1891] 1 Ch. 213.

66. Supra, note 62 .

67. Supra, note 8. 
In the Oakwood Petroleums (No. 2) ${ }^{68}$ case, the plan of arrangement proposed that the creditors of the corporation be divided into secured creditors and unsecured creditors. The rationale for placing the secured creditors into a single class was that each of the secured creditors held similar security in the form of assignments of oil and gas assets under s. 185 (formerly s. 177) of the Bank Act. ${ }^{69}$ The plan of arrangement divided the shareholders of the corporation into two separate classes. Preferred shareholders were in one class and the common and Class " $A$ " nonvoting shares of the corporation were in a separate class. Holders of the shares of a subsidiary corporation included in the plan of arrangement were also placed in a separate class.

It was argued in the Oakwood Petroleums (No. 2) ${ }^{70}$ case that a crucial element of identity of interest is whether the creditors are able to look to the same source or fund for repayment of their loan as originally granted by the debtor corporation. Where creditors hold security over different assets to which they are looking for repayment of their respective loans, the requirement of identity of interest is not present. It was argued that the very fact of holding separate security on different assets to paraphrase Esher L.J. in Sovereign Life, " . . . will give rise to a different state of facts which may affect the creditors' individual minds and judgements differently in respect of the proposed plan."

This argument was rejected by Mr. Justice Forsyth. He expressed the concern that this approach to classification would result in excessive fragmentation of classes making it difficult if not impossible to complete any plan of arrangement. He states at page 147 of his judgment:

First, it is clear that the $C C A A$ grants a court the authority to alter the legal rights of parties other than the debtor company without their consent. Second, the primary purpose of the Act is to facilitate reorganizations and this factor must be given due consideration at every stage of the process, including the classification of creditors made under a proposed plan. To accept the 'identity of interest' proposition as a starting point in the classification of creditors necessarily results in a 'multiplicity of discrete classes' which would make any reorganization difficult, if not impossible, to achieve.

In the case Northland Properties Limited v. Excelsior Life Insurance Company of Canada ${ }^{71}$ the plan of arrangement contemplated placing all first-mortgage holders on various properties held by the debtor into one class. It was argued that this composition of classes was unfair because some of the first-mortgage holders were fully secured and other first-mortgage holders were facing a deficiency. The court rejected this argument for very similar reasons to those of Justice Forsyth in the Oakwood case. It held that recognition of such differences for purposes of classification would result in excessive fragmentation and make it impossible to implement any plan of arrangement. McEachern C.J.B.C. stated at page 130 of his judgment:

I wish to add that in any complicated plan under this Act, there will often be some secured creditors who appear to be oversecured, some who do not know if they are fully secured or not, and some who appear not to be fully secured. This is a variable cause arising not by any difference in legal interests, but rather as a consequence of bad lending, or market values, or both.

McEachern, C.J.B.C. adds at page 131:

. . . the authorities wam us against second-guessing businessmen (see Re Alabama supra at p. 244).

In this case, the companies and their advisors, the Bank and its advisors, and all the creditors except

68. Supra, note 6.

69. R.S.C. 1985 , c. B-1.

70. Supra, note 6.

71. (1989), 34 BCLR (2d) 122. 
the two appellants, voted for the plan. As the authorities say, we should not be astute in finding technical arguments to overcome the decision of such a majority.

Some general conclusions can be drawn from the case law relating to classification. The first is that parties, whether creditors or shareholders, that have different priorities in terms of their respective interests should not be placed in the same class. For example, it has been held that first and second mortgage holders should not be placed in the same class. ${ }^{72}$ Nor should secured and unsecured creditors be placed in the same class. Preferred and common shareholders or different classes of them generally should be in separate classes. In the case Re Second Standard Royalties $\mathrm{Ltd}^{73}$ Orde J.A. of the Ontario Court of Appeal, in considering an application to sanction an arrangement with shareholders, states at page 300:

I think it must be a fundamental factor for consideration in all such schemes or arrangements that the proposed sacrifice or other modification of charter-rights must be borne proportionately by all those members of the class affected, so that a minority, while opposed, may at least feel that the majority are all giving up as much proportionately as they are. If the scheme may have the effect of enabling the majority, either directly or through the medium of the directors, whom the majority necessarily have it in their power to elect, to benefit some members of the class at the expense of others, then the scheme should be scrutinized with great care, and ought in most cases to be rejected. (emphasis added)

However, where the corporation is insolvent and there is no equity in the "traditional sense" the preferred shareholders should not be given a class that could provide them with a virtual veto over the reorganization. ${ }^{74}$

Community of interest is the key issue in classification and it would appear that the courts are willing to overlook what they consider to be minor differences in the nature of the interests held by the various parties in the interest of facilitating reorganization.

\section{DISCLOSURE}

The corporations involved in a reorganization plan have an obligation to disclose all material facts relating thereto to their creditors and shareholders. In the case of public corporations, which are reporting issuers under various securities legislation, this obligation is usually satisfied by delivering to creditors and security holders an information circular or similar disclosure document containing information which is specifically required or permitted under applicable securities laws. ${ }^{75}$ In some cases the level of required disclosure is raised in court prior to the information circular being sent. The court will usually be reluctant to rule on the adequacy of disclosure at the preliminary stages of proceedings but may give some guidance as to the standard it expects.

In the Amoco Canada/Dome case, Justice Forsyth ordered that Dome provide the shareholders "with full, true and plain disclosure of all material facts surrounding the Plan of Arrangement as regards the Shareholder Group in accordance within the applicable requirements of the $C B C A$ and the regulatory agencies having jurisdiction over the financial affairs of Dome". He further ordered that each member of the public unsecured voting group (i.e., public unsecured creditors) who

72. Re Wellington supra, note 38.

73. (1930), 66 O.L.R. 288; see also Re Standard Manufacturing Co. and Baird (1984), 5 D.L.R. (4th) 697.

74. Per Forsyth J. \& Kerans J.A.: Savage v. Amoco Acquisition, supra, Part III.

75. The writers wish to express their thanks to Gregory Mould of Howard, Mackie for his contribution to this section of the paper. 
requested information was to be provided with an information circular of the type used in Eurodollar solicitations and the material sent to the shareholders. However, he specifically ordered that any submission concerning the adequacy of the disclosure to the shareholders concerning the plan of arrangement was to be addressed at the faimess hearing. In other words, the applicants assumed the risk that the disclosure was adequate.

The cases relating to court approval of reorganization plans have established that there must be disclosure of all material information. Generally, the information required or permitted to be included in disclosure documents is of an historical or factual nature relating to the corporations involved in the proposed reorganization. However, even if the parties to the proposed reorganization have satisfied all the technical requirements specified by applicable securities law, they may still face a court challenge on the basis that there has been a failure to disclose so called "soft information". "Soft information" is the term used to refer to information concerning some subjective analysis or extrapolation. In the case of an oil and gas company, it may consist of projections, forecasts, estimates or opinions of reserves, future prices and in particular, internally generated asset appraisals or earnings projections or evaluations of the issuer or other corporations involved in the reorganization. The definition of, and failure to disclose, soft information has become an increasingly contentious matter in litigation relating to corporate reorganizations, especially in the United States. Disgruntled security holders may argue that soft information ought to be disclosed, either on the basis that its disclosure is material to security holders or that the failure to disclose the information renders information which has been disclosed misleading. Historically, the policies of the United States Securities and Exchange Commission ('SEC') have prohibited the inclusion of soft information in documents filed under the Securities Act of 1933 and the Securities Exchange Act of 1934. During the period in which SEC policies prohibited disclosure, the courts generally relied upon the SEC's policies to hold that disclosure of soft information was not required ${ }^{76}$ In recent years, the SEC's traditional policy of prohibiting or restricting the use of soft information has changed to one of encouraging or requiring disclosure of soft information in certain circumstances. However, the court's response to the change in SEC policies has not been uniform. The Second Circuit ${ }^{7}$ and the Seventh Circuit ${ }^{78}$ have generally held that there is no duty to disclose soft information. The Ninth Circuit has generally determined that there is no duty to disclose soft information, ${ }^{79}$ although more recent cases suggest some change in that position. ${ }^{80}$ In Flynn v. Bass Brothers Enterprises, ${ }^{81}$ the Third Circuit held that a duty to disclose soft information is to be determined "on a case by case basis, by weighing the potential aid such information will give a shareholder against the potential harm, such as undue reliance, if the information is released

76. Marsh v. Armada Corp., 533 F. 2d 978 (6th Cir. 1976); Straus v. Holiday Inns, Inc., 460 F. Supp. 729 (S.D.N.Y. 1978); Union Pac. R.R. v. Chicago \& N.W. Ry., 226 F. Supp. 400 (N.D. III. 1964); Rodman v. Grant Found, 608 F.2d 64 (2d Cir. 1979).

77. Gerstle v. Gamble-Skogmo, Inc., 478 F.2d 1281 (2d Cir. 1973).

78. Panter v. Marshall Field \& Co., 646 F. 2d 271 (7th Cir.), cert. denied, 454 U.S. 1092 (1981).

79. Vaughn v. Teledyne, Inc., 628 F. 2d 1214 (9th Cir. 1980); South Coast Services Corp. v. Santa Ana Valley Irrigation Co., 669 F. 2d 1265 (9th Cir. 1982).

80. Plaine v. McCabe, 797 F. 2d 713 (9th Cir.) superceding 790 F. 2d 742 (9th Cir. 1986); Texas Partners v. Conrock Co., 685 F. 2d 1116 (9th Cir. 1982), cert. denied, 460 U.S. 1029 (1983).

81. 744 F. 2d 978 (3rd Cir. 1984). 
with a proper cautionary note".$^{82}$ The court in Flynn held that the factors a court must consider in making such a determination are: the facts upon which the information is based; the qualifications of those who prepared or compiled it; the purpose for which the information was originally intended; its relevance to the shareholder's impending decisions; the degree of subjectivity or bias reflected in its preparation; the degree to which the information is unique; and the availability to the investor of other more reliable sources of information.

A leading case on the question of soft information appears to be Starkman v. Marathon Oil Co. ${ }^{83}$ which establishes the "substantially certain to hold" test. The court suggested a three-pronged analysis to determine the requirement to disclose soft information: a duty to disclose must exist; the omission must meet the TSC Industries materiality test $;^{84}$ and the duty to disclose would be imposed "only if the nondisclosure of the particular material facts make misleading the affirmative statements otherwise required under federal securities law and SEC regulations" ${ }^{85}$ With respect to the issue of a duty to disclose, the Sixth Circuit held that "our cases fully support a rule under which a tender offer target must disclose projections and asset appraisals . . . only if the predictions underlying [them] are substantially certain to hold" ${ }^{86}$

Thus, it would appear that in appropriate circumstances there may be a duty to disclose soft information. In preparing disclosure documents, the parties to a proposed reorganization, acquisition or merger must address the difficult issue of whether certain soft information will be disclosed at an early stage.

\section{SUMMARY PROCEEDINGS BEFORE THE COURT}

By its very nature a reorganization plan requires prompt consideration by the creditors, the shareholders and the court. In most cases a reorganization plan is fragile and will not withstand lengthy litigation. The proponents of the plan will wish to move with great speed, while parties opposed or uncommitted to the plan will seek as much information as possible and time to conduct their own investigations, perhaps at the expense of the company. It falls on the court to balance the interests of the anxious proponents of the plan with the interests of opposed or reluctant parties.

Both the $C B C A$ (s. 248) and the $A B C A$ (s. 241) provide as follows:

Where this Act states that a person may apply to a court, the application may be made in a summary manner by petition, originating notice of motion, or otherwise as the rules of court provide, and subject to any order respecting notice to interested parties or costs, or any other order the court think fits.

"Person" is defined to include a body corporate. Further, as pointed out in Part II above, the $C C A A$ provides for summary proceedings by way of petition or originating summons or notice of motion in accordance with the practice of the court in which the application is made and permits appeals only with leave of the court.

82. Ibid. at 988.

83. 772 F. 2d 231 (6th Cir. 1985), cert. denied, 106 S.Ct. 1195 (1986).

84. TSC Industries v. Northway, Inc., 426 U.S. 438 (1976), which held that an omitted fact is material if there is a substantial likelihood that a reasonable shareholder would consider it important in deciding how to vote.

85. Starkman at 238.

86. Ibid. at 241. 
Thus applications to approve plans of arrangement under the $C B C A$, the $A B C A$ and the $C C A A$ are to be summary in nature. The description of the plan and the arrangement agreement are usually contained in an affidavit or affidavits which will be filed and served with the petition or originating notice of motion. The applicant applies to the court, sometimes on an exparte basis, for directions as to service and for directions as to the calling of meetings of the various classes of creditors and shareholders. If procedure or classification appear to be contentious issues, the applicant is well advised to make the application to set procedures and classes on notice to all interested parties.

Where the corporation involved has numerous creditors and shareholders, it may not be apparent as to who will wish to make representations at the fairness hearing. A procedure was adopted in the Amoco Canada/Dome proceedings whereby persons who wished to make submissions were required to file a "notice of intention to appear" akin to the type of notice filed in regulatory hearings. A notice of intention to appear would generally contain a brief statement of the person's interest and an address for service. In most cases the court orders that only those persons who file a notice of intention to appear will receive further material relating to the court proceedings. However, the requirement that an interested party file a notice of intention to appear will not relieve the applicant from ensuring that all creditors and shareholders receive appropriate information circulars regarding the proposed plan.

Generally the required votes to be taken under the $C C A A$, or the $A B C A$ or as ordered by the court under the $C B C A$, will be taken and tabulated before any affidavits required for the fairness hearing are required to be filed and served. The court will usually order that the applicant file any affidavits in support of approval of the plan by a stipulated time and allow any party wishing to file affidavits against the approval to do so within a reasonable time thereafter. The court will usually set a time in which cross-examinations on the affidavits must take place.

The affidavits of the applicant will of course set out the results of the votes taken for each class of creditors and shareholders. The affidavits will also include such information as the applicant deems necessary to convince the judge that the proposed plan is fair. The applicant will want to take care not to introduce facts that were not included in the information circular and which other parties may argue should have been disclosed therein as being material.

Parties who oppose the plan will often seek more information than contained in the information circulars or affidavits. For example, if "fairness opinions" of experts are included in the information circular and affidavits it is not unusual for parties to seek all the information that was considered in the preparation of the fairness opinions. If the party requesting the information is entitled to receive it, review it, and prepare its own reports, lengthy delays may occur. In the Amoco Canada/ Dome arrangement a number of shareholders sought the production of detailed information which would enable them to prepare, at the corporations' expense, their own evaluation of the worth of Dome. The directors had already obtained fairness opinions the conclusions of which were included in the information circular. Justice Forsyth declined to grant the shareholders' request. Amoco Canada and Dome did not put forward affidavit or viva voce evidence from the parties who prepared the fairness opinions but rather chose to rely on the fact that the market had been completely canvassed for potential purchasers of Dome and that Amoco 
Canada made the highest bid. Justice Forsyth accepted this as an indication of the true value of the company. Further, he put heavy emphasis on the fact that sophisticated lenders, primarily unsecured financial institutions, had agreed to accept cash and security amounting to $\$ .45$ on the dollar. It was not necessary for him to consider on the fairness opinions at the hearing. In situations where a plan does not include an acquisition or a canvass of the marketplace the court may well order full production of all documents leading up to the completion of fairness opinions.

In complex corporate reorganizations the potential for delay exists by parties demanding extensive production of documents and conducting lengthy examinations on affidavits. A judge who is called upon to determine what information should be produced may feel compelled to follow the rules of pre-trial discovery so that the faimess of the plan can be tested. This is especially true when the applicant chooses to rely on certain information and opinions in possession of the company but does not wish to disclose the backup information relevant to the opinions. The requests for information may come during cross-examination on the affidavits. If the applicant refuses to produce the information the other party may apply to the court for production. Such applications take time. Further, an opponent to the plan may wish to examine a person who has not sworn an affidavit. If the applicant refuses to produce the witness the party wishing to examine may seek to use rule 266 of the Rules of Court dealing with examination of witnesses for the purpose of using their evidence at the faimess hearing.

Therefore, while the court-approval process is "summary", the time between the commencement of proceedings and the fairness hearing, including appeals, can be lengthy. The Alberta courts have gone to great lengths to ensure that plans of arrangement are not defeated or discouraged because of an inability of an applicant to get to court in a timely manner. However, once the matter is before the court the effectiveness of the summary procedure will be determined by the ability of the judge to deal quickly and effectively with difficult questions such as production of documents, examination of witnesses and timing generally. In many complicated reorganizations a judge is often designated by the Chief Justice to hear the matter from start to finish. This generally serves to expedite the proceedings often to the chagrin of some parties. However, it is trite to state that while an expeditious hearing is desirable, summary proceedings must be conducted within the rules of natural justice.

\section{A. THE USE OF DECLARATORY RELIEF}

In some cases the proponents of a reorganization plan may find it expedient to seek certain declarations from the court by way of preliminary application if they have concerns about their ability to proceed under a certain statute. Thus in the Amoco Canada/Dome Plan of Arrangement the applicants did not wish to embark on lengthy and costly court proceedings under the $C B C A$ only to find that the courts limited the scope of section 192 (see Part III). They felt it expedient to make a preliminary application to the court for declarations that the plan of Arrangement as contemplated in their Arrangement Agreement was an arrangement within the meaning of section 192 of the $C B C A$; the court had jurisdiction to approve the Plan of Arrangement; and the final order, if granted, would be binding on non-assenting shareholders and creditors of Dome. The court granted them the declarations. 
Section 11 of the Judicature $A c t^{87}$ states as follows:

No action or proceeding shall be open to objection on the ground that a mere declaratory judgement or order is sought thereby and the court may make binding declarations of right whether or not any consequential relief is or could be claimed.

The Alberta courts are prepared to make declarations in commercial situations. In so doing they have employed a test that was set down by the House of Lords in the 1921 case of Russian Commercial and Industrial Bank v. British Bank For Foreign Trade. ${ }^{88}$ In the 1936 Alberta case of Kent Coal Co. Ltd. v. Northwestern Utilities Ltd.$^{89}$ certain declarations were sought by a coal mining company relating to its operations in an area where a utility company had a gas main. McGillivray J.A. stated:

To apply the test mentioned by Lord Dunedin in the Russian Commercial \& Industrial Bank case, supra, the question here raised is surely a real and not a theoretical question, the plaintiffs certainly have a real interest in raising it and certainly have secured a proper contradicter in the defendant. Again this is a case in which it is all important that the plaintiff company to use the language of Lord Sumner in the Russian Commercial and Industrial Bk. case, "may know what business course to take without having to run the risk of acting and finding themselves liable in damages, when at last the matter is brought before the court.

It appears that "damages" in the above quotation can be extended to thrown away costs if the courts ultimately decide that the arrangement was brought under the wrong statute. Neither the Court of Queen's Bench nor the Court of Appeal in the Amoco Canada/Dome case expressed any concerns that the preliminary declarations were not warranted. ${ }^{90}$

\section{THE DUTIES OF THE COURT IN APPROVING AN ARRANGEMENT}

In considering whether an arrangement should be approved the court must consider the "faimess" of the arrangement to all parties. The law to be considered in assessing the "faimess" of a plan of arrangement is basically the same whether the plan is made under the $C C A A$, the $C B C A$ or the $A B C A$.

The court's duty was described in the judgment of Middleton J.A. in Re Dairy Corporation of Canada Ltd. ${ }^{11}$ in the following terms:

Upon this motion I think it is incumbent upon the judge to ascertain if all statutory requirements which are in the nature of conditions precedent have been strictly complied with and I think the judge also is called upon to determine whether anything has been done or purported to have been done which is not authorized by this statute. Beyond this there is, I think, the duty imposed upon the Court to criticize the scheme and ascertain whether it is in truth fair and reasonable.

Middleton J.A. had before him an application to approve an arrangement under the Ontario Companies Act, R.S.O. 1927, c. 218. However, the principles are the same under the $C C A A .^{92}$

The English case Re Dorman, Long \& Co. Ltd.; Re South Durham Steel and Iron Co. ${ }^{93}$ sets out the court's duty in these terms:

87. RSA 1980 , c. J-1.

88. [1921] All E.R. 329.

89. [1936] 4 D.L.R. 337 at 355; (see also Jepson Estate v. Westfair Foods Lid. (Alta. Q.B.) unreported (oral decision), 15 1989, J.D. of Calgary, Q.B. 8901-00647.

90. For a full discussion of the law relating to declarations see Sama, The Law of Declaratory Judgments (2nd ed. 1988).

91. [1934] 3 D.L.R. 347 at 348.

92. Re Wellington Building Corporation Limited, supra, note 38.

93. [1933] All E.R. 460 per Maugham J. at 466. 
I will first state my view as to the function of the court in determining whether the compromise or arrangement should be sanctioned by the court. It is plain that the duties of the court are twofold. The first is to see that the resolutions are passed by the statutory majority in value and number, in accordance with s. 158 (2), at a meeting or meetings duly convened and held. Upon that depends the jurisdiction of the court to confirm the scheme. The other duty is in the nature of a discretionary power, and it has been the subject of two decisions in the Court of Appeal, . . .

The court must look at the scheme and see . . . whether the scheme is a reasonable one or whether there is any reasonable objection to it, or such an objection to it as that any reasonable man might say that he could not approve of it . . . the court . . . must be satisfied that the proposal was at least so far fair and reasonable, as that an intelligent and honest man, who is a member of that class, and acting alone in respect of his interest as such a member, might approve of it.

This case was cited with approval in Alberta by Chief Justice Moore in Re Audax Gas \& Oil Ltd. $;^{94}$ by Stevenson J.A. in Re Associated Investors of Canada Ltd. $;^{95}$ and by Hetherington J.A. in the case Premji v. Amoco Acquisition Co. ${ }^{96}$

In respect of the first duty there are a number of factors the court will consider, including whether the requisite statutory majority vote, where applicable, was attained. The onus to establish that the meetings were properly convened, the proper voting procedures followed and the recorded results accurate will be on the proponent. ${ }^{97}$

The issue of classification has been the subject of considerable attention at fairness hearings (see Part IV). If the order directing the calling of one or more meetings and the classification of creditors and shareholders was obtained ex parte, a creditor or shareholder who objects to the classifications may raise the issue for the first time at the fairness hearing. In Fraser \& Stewart, Company Law of Can$a d a,{ }^{98}$ it is stated:

The responsibility for determining what creditors are to be summoned to a meeting as constituting a class is the applicant's. An objection to the presence of particular creditors as having interests competing with the others must be taken on the application for sanction. If the meetings are incorrectly convened or constituted or an objection as aforesaid is taken, the applicant takes the risk of having the application dismissed (Practice Note, [1934], W.N. 142 (Eve. J.)).

A developing practice has been for the proponents of a plan to seek a court order on notice to all interested persons dealing with preliminary matters such as the calling of meetings and the classification of creditors. This procedure was followed by the applicants in the Oakwood Petroleums Ltd. case; the Re Northland Properties Ltd. case $^{99}$ and the Amoco Canada/Dome case. ${ }^{100}$

Another issue the court will assess as part of its first head of duty is whether or not there has been proper disclosure to the creditors in order to enable them to make a reasoned judgment in respect of the proposed arrangement (see Part V). In the case of $\operatorname{Re}$ Alabama ${ }^{101}$ Fry L.J. stated:

If the creditors are acting on sufficient information, and with time to consider what they are about, and are acting honestly, they are, I apprehend much better Judges of what is to their commercial advantage then the Court can be ...

94. (1985), 42 Alta. L.R. (2d) 353 at 360-361.

95. (1988), 60 Alta. L.R. (2d) 242 (Alta. C.A.).

96. (1988), 61 Alta. L.R. (2d) 279 (Alta. C.A.).

97. Oakwood Petroleums Lid. (No. 2), supra, note 6; Re Langleys Lid., [1938] O.R. 123.

98. 5th ed. (1962).

99. Vancouver Registry No. A880966.

100. Savage v. Amoco Acquisition Co. Lid., supra, note 5.

101. Supra, note 65. 


\section{As noted by Stanley E. Edwards ${ }^{102}$}

It is axiomatic that the parties will be unable to exercise properly their voting power or protect adequately their interests unless they are as completely and fairly informed as possible as to the proposal, the facts and the law.

An issue that may come up from time to time is whether there has been disclosure of appropriate information relating to the different treatment of classes of creditors, or creditors within the same class under the plan of arrangement. If creditors are not going to be treated equally in the proposed plan of arrangement there must be full disclosure to the other creditors. Absent such disclosure, it is arguable that the subject arrangement is voidable at the instance of the other creditors. ${ }^{103}$

Creditors will rarely receive equal treatment under a plan but will usually be treated according to the nature of their interests. However, there is no unfairness in differential treatment as long as it is based upon objective criteria, such as the nature of the security held by the particular creditor and so long as there is complete disclosure of the material facts relating to the differentiation in the information circular.

The onus is on the proponent of the plan to adduce sufficient evidence to convince the court that the plan is fair and reasonable. The courts have taken the view that if the plan receives overwhelming support from the members of the particular classes, and as long as the statutory requirements have been met, they will not be quick to reject it. ${ }^{104}$ However, even where overwhelming support is present, the court will still carefully examine the details of the plan, especially where there is dissent, to ensure that the plan is objectively fair and reasonable. Simply to accept the majority view on this issue is an abdication of the duty of the court. As stated by Collins J. in the case In re Canadian Cottons Limited: ${ }^{105}$

The court also considered carefully the argument of counsel for the company that the large shareholders support the scheme and that, therefore, the opposition of the small minority should be disregarded by the court. The court can only accede to this argument to the extent that the opposition of the small minority shareholders is not well founded. Otherwise, there would be no advantage in requiring such scheme to be submitted to the court for sanction if the will of the majority were to prevail regardless of the law, the equity, the justice or injustice of the scheme.

The court will assess whether the amount that individual creditors are receiving in respect of their claims is objectively fair and reasonable. It may require evidence that the creditor would in all probability have received at best an equivalent amount and probably less upon a liquidation of the corporation. For the plan to be adjudged fair the court will usually have to be satisfied that the secured creditors are receiving at least as much as they would receive if they were allowed to realize upon their security. However, the court will be careful not to cater to the special needs of any particular group "but must consider the interests of all involved". ${ }^{106}$

Where there are dissenting secured creditors the problem of valuation can become a major issue. There may be a substantial difference between the fair market value of a property and its liquidation value. Obviously the secured creditor will

102. Supra, note 5.

103. See Hochberger v. Rittenberg (1917), 36 D.L.R. 45 (S.C.C.); LaPréwayance v. Giroux (1932-33), 14 C.B.R. 174.

104. See Re Alabama, supra, note 65; Re Audax, supra, note 94 .

105. (1951), 33 CBR 38 at p. 53.

106. Supra, note 57 . 
seek the former and the corporation may only be willing to offer the latter. Expert evidence will be required at the hearing to establish the value of the assets covered by the security. If the court determines that the amount to be paid the secured creditor exceeds what the creditor would receive upon liquidation it may approve the plan.

The valuation of security on oil and gas properties may present unique problems as valuations can vary substantially depending upon the underlying assumptions relating to proven and probable reserves, production levels, price forecasts, inflation factors and so forth. It is not within the scope of this paper to deal with valuation issues other than to state that the court in approving the plan will have to be satisfied that on the evidence the plan provides fair value to the secured creditor.

\section{CONCLUSION}

Recent cases have confirmed the public policy of promoting the continuance of insolvent corporations. In furtherance of this goal the courts have been prepared to interpret statutory provisions relating to reorganizations and plans of arrangements liberally to provide insolvent corporations with an opportunity to survive. The concept of "fairness" has not been confined to the fairness hearing itself. Recent cases demonstrate the desire of the courts to adopt procedures throughout the proceedings that will postpone the concerns of parties with pre-disposed negative views towards a plan to the fairness hearing. The courts have recognized the desirability of addressing such concerns in light of the plan's overall fairness. The courts are not inclined to allow the reorganization to be destroyed before it can be considered on its merits by all the creditors, shareholders and the court itself. 